\title{
Os Guarani e seus artefatos líticos: um estudo tecnológico no sul do Brasil
}

Rafael Guedes Milheira*

MILHEIRA, R.G. Os Guarani e seus artefatos líticos: um estudo tecnológico no sul do Brasil. R. Museu Arq. Etn., São Paulo, n. 21, p. 129-152, 2011.

Resumo: Neste trabalho apresentamos uma análise tecnológica para caracterizar a cadeia operatória de artefatos líticos provenientes de sítios arqueológicos da cultura Guarani, localizados na margem sudoeste da Laguna dos Patos e Serra do Sudeste - Rio Grande do Sul. Percebendo uma variação nas estratégias de obtenção, manufatura, uso e descarte de matérias-primas como calcedônia, arenito friável e quartzo, propomos uma discussão sobre as dimensões do território de domínio Guarani, tecnologias de curadoria e expediência, função de artefatos e padrões de descarte.

Palavras-chave: Arqueologia Guarani - Tecnologia lítica- estratégias de obtenção de recursos - território de domínio - uso e descarte de materiais.

\section{Introdução e objetivos da pesquisa}

$\mathrm{O}$ estudo das indústrias líticas presentes em sítios arqueológicos Guarani tem sido historicamente relegado a um segundo plano na arqueologia brasileira. Grande parte deste descaso atribui-se ao pressuposto de que os grupos Guarani, detentores da tecnologia cerâmica, não teriam o conhecimento para o trabalho aprimorado das rochas, se comparado às tradições líticas especializadas do Brasil.

Este pré-conceito já havia sido apontado anos atrás (1989), ${ }_{1}^{1}$ por La Salvia e Brochado ao

$\left.{ }^{*}\right)$ Instituto de Ciências Humanas da Universidade Federal de Pelotas. LEPAARQ/UFPel. >milheirarafael@gmail.com> (1) "Se os elementos estão presentes é porque tiveram uma importância no seu comportamento. É fácil fugir do problema alegando reocupação de sítio, mas difícil buscar os processos de interação havidos entre grupos de bases culturais diferentes comentarem que as indústrias líticas presentes nos sítios arqueológicos Guarani encerram em si uma série de questões que podem ser desenvolvidas pelo arqueólogo em paralelo ao estudo das indústrias cerâmicas.

À luz de análises tecnológicas, as indústrias líticas desenvolvidas por grupos Guarani têm sido alvo de olhares mais atentos quanto a sua

que se encontram e trocam suas experiências, e estas, devem ser observadas e o que é mais importante e difícil, detectadas. O documento do arqueólogo é o elemento material e sua presença não pode jamais ser relegada a planos secundários ou desprezados. A mesma atenção que vamos oferecer à cerâmica devemos dar ao lítico que está associado, e a este por ser escasso e diferente, o tratamento deva ser até diferenciado. Temos notado nos sítios por nós percorridos que o lítico sofre uma influência muito grande e vamos desde sua ausência até uma presença bastante significativa. Como explicar tal ocorrência?" (La Salvia e Brochado 1989: 149). 
potencialidade em termos de esclarecimento de aspectos da cultura (Dias \& Hoeltz 2002; Luz \& Faccio 2006). Se a preocupação de La Salvia e Brochado (op cit) era de que os materiais líticos eram apenas descritos em suas características tipológicas para afirmar o que já havia sido dito através da cerâmica, atualmente, vemos um significativo aumento de pesquisas que vêm buscando "um olhar tecnológico" para explicar processos culturais, noções de território e práticas quotidianas relacionadas à obtenção, manufatura, uso e descarte de materiais líticos.

Neste trabalho, partimos da noção de que os materiais líticos devem ser estudados em sua particularidade, ou, como diriam La Salvia e Brochado (1989: 149): “(...) estudar o lítico como lítico, definir o que realmente é da cultura, podendo ser modal ou grupal, e o que não lhe pertence, mas porque está ali presente. Se, entretanto, partirmos das ideias de reocupação de sítios, aproveitamento de material abandonado, intrusão por troca ou outras proposições deste padrão, então é melhor nem iniciarmos".

Num primeiro momento da pesquisa (Milheira 2008a, 2008b; Milheira \& Alves 2009), concentramo-nos em analisar a presença dos artefatos líticos e suas respectivas matérias-primas. Com base nesta análise foi possível discutir questões de estratégias de assentamento e de obtenção de recursos líticos no território de domínio - o teko'á - para então compreender a dimensão deste território e suas áreas de influência cultural. Além disso, o material lítico em conformação com os demais vestígios arqueológicos serviu como suporte importante para identificação de áreas de atividade intrassítio no espaço da aldeia Guarani litorânea do sítio PS-03-Totó o que nos possibilitou inferir sobre aspectos de definição do espaço doméstico e higienização.

Em complementação a este exercício inicial, propomos aqui uma análise tecnológica que envolve a identificação e reconhecimento de etapas da cadeia operatória relativas à indústria lítica. Através de uma análise mais acurada da indústria, buscamos identificar as diferentes etapas do ciclo de vida dos artefatos (Schiffer 1972, 1987), desde os suportes básicos até os resíduos finais.
Este processo que envolve: obtenção e transporte da matéria-prima, manufatura, uso, reciclagem e descarte evidencia um planejamento cognitivo coletivo inerente à esfera social. Considerando estas questões, nosso estudo abrange discussões acerca da sequência operacional de manipulação de artefatos líticos, abordando temas como planejamento, tecnologia e territorialidade.

\section{Área da pesquisa: características físicas da região de estudo}

A área de pesquisa envolve um conjunto de sítios arqueológicos localizados na Planície Costeira do Rio Grande do Sul, mais especificamente na margem sudoeste da Laguna dos Patos, município de Pelotas-RS. Nessa região dominam os modelos esculpidos em depósitos de origem continental, ocorrendo em pequenos trechos, geralmente às margens da referida laguna, os modelos derivados do remanejamento eólico, origem das dunas atuais. Predomina vegetação pioneira, já alterada pela ação antrópica (Radam Brasil 1986: 325).

O município se localiza numa região classificada como Unidade Geomorfológica Planície Alúvio-Coluvionar, que corresponde à superfície plana, rampeada suavemente para leste; em alguns trechos descontínuos, posicionada entre a Planície Lagunar a leste e os relevos do Planalto Sul-Riograndense a oeste (Tomazelli e Villwock 2000). Nessa unidade: “(...) predominam os modelos planos ou embaciados, resultantes da convergência de leques coluviais de espraiamento, cones de dejeção ou concentração de depósitos de enxurradas nas partes finais das rampas de pedimentos. Ocorrem ainda formas de topo plano ou baixos tabuleiros. Nas proximidades da Laguna dos Patos corresponde a antigas dunas dissipadas, onde se processou uma dissecação do tipo homogênea com densidade de drenagem, fina e média, (...) trata-se de uma área de deposição eólica, oriundos de processos pedogenéticos que se instalaram na área" (Radam Brasil 1986: 325).

Em termos de matérias-primas líticas, na região litorânea da Laguna dos Patos não são 
conhecidos afloramentos rochosos dos tipos identificados nos sítios arqueológicos. Esta informação recorrente na literatura especializada foi corroborada em nossos trabalhos de campo, já que, durante as saídas para reconhecimento dos aspectos ambientais e prospecção arqueológica, não foi identificado qualquer tipo de deposição de matéria-prima lítica em forma de seixos ou matacões, que pudessem ser utilizados como material para lascamento.

\section{O contexto arqueológico regional}

A área de pesquisa vem sendo alvo de um estudo na linha da Arqueologia Regional desde o início dos anos 2000, no âmbito do Projeto de Mapeamento Arqueológico de Pelotas e Região (PMAPR), em desenvolvimento pelo LEPAARQ-UFPel.

Através de um levantamento Arqueológico por Amostragem Probabilística Estratificada (Redman 1973; Plog 1976; Dias 2003), que envolve a varredura intensiva de unidades amostrais em campo, foram identificados até o momento na região litorânea um conjunto de sete sítios ar- queológicos. Destes, quatro tornaram-se objeto de pesquisas efetivas que interessam diretamente à discussão proposta. Trata-se de dois sítios arqueológicos que se localizam na Ilha da Feitoria (PT-01-Sotéia e PT-05-Lagoinha) e outros dois na Praia do Totó (PS-02-Camping e PS-03-Totó), assentados sobre pequenas elevações naturais do terreno em meio à mata de restinga (ver mais detalhes em Milheira 2008a, 2008b).

As intervenções arqueológicas que seguiram uma sequência de sondagens e escavação de unidades com plotagem individual dos vestígios arqueológicos foram realizadas no intuito de delimitar a área de ocupação de cada sítio, identificar estruturas arqueológicas em superfície e/ou subsuperfície, coleta de vestígios materiais para análise tecno-tipológica e coleta de amostras para datação. Desta forma, pudemos discutir questões específicas de cada sítio em seus aspectos funcionais e a relação destes como unidades inseridas num sistema de assentamento mais amplo que envolve não somente a região litorânea, mas também a região da serra do Sudeste.

Pudemos também desenvolver questões relativas à intensidade de ocupação - se permanente ou semipermanente - e compor um mo-

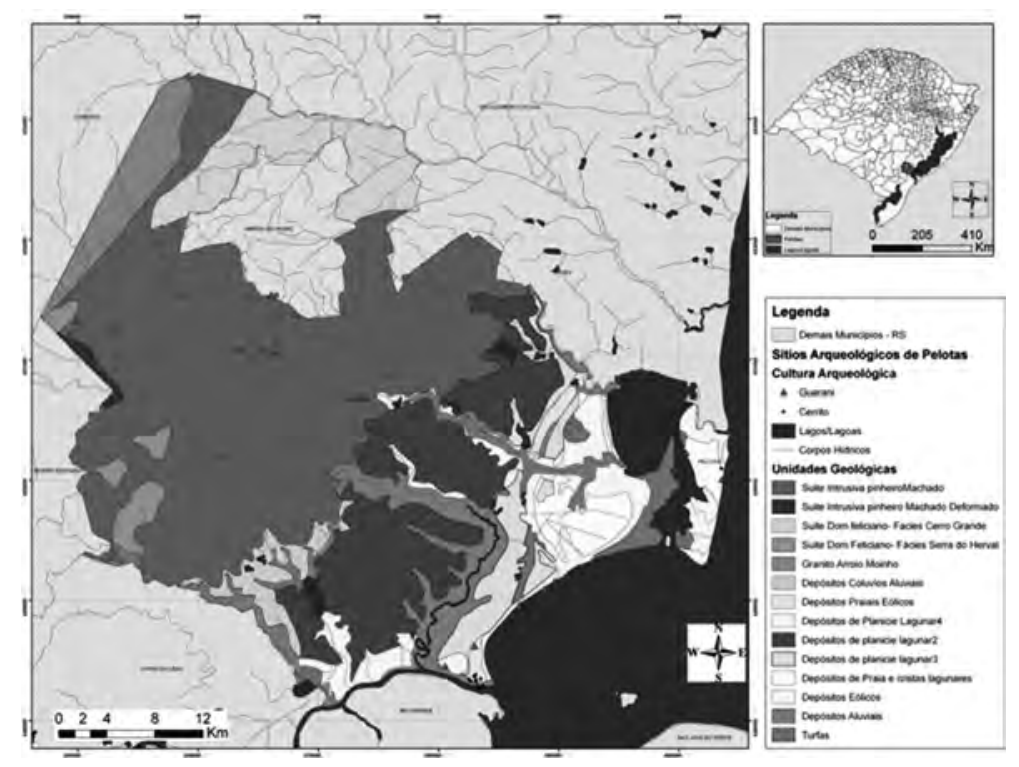

Fig. 1. Mapa com matriz geológica e localização dos sítios arqueológicos na margem sudoeste da Laguna dos Patos, município de Pelotas. Mapa modificado de Marth, Koester e Arndt (2008). 
delo regional de ocupação Guarani, que se caracteriza por determinadas estratégias de ocupação do espaço e aquisição territorial, envolvendo um sistema tradicional de manejo das áreas de assentamento numa estrutura histórica de longa duração. Neste modelo, propomos que os sítios arqueológicos Guarani, localizados na região da Serra do Sudeste, mais especificamente no vale do Arroio Andrade, compõem um sistema de assentamento regional. Nesta localidade, o padrão de distribuição dos sítios arqueológicos formando um conjunto concêntrico (cluster), se aproxima do padrão de assentamento recorrente para sítios arqueológicos da cultura Guarani, padrão este comumente descrito também em exemplos etnográficos e que demonstra uma forma de assentamento estrutural (Noelli 1993; Garlet 1997; Fausto 2001). A ocupação serrana seria contemporânea à ocupação no litoral, apontando um horizonte cronológico em torno de $510 \pm 70$ A.P. ou o ano de 1440 da Era Cristã (protocolo 1968 do LVD-FATEC), datação esta realizada através da técnica de Termoluminescência, com base em uma amostra de cerâmica proveniente da parede de uma urna funerária escavada na aldeia do sítio PSGPA-04-Ribes.

Partindo do conceito de "enxameamento" (Brochado 1984; Noelli 1993), em que os grupos Guarani expandem seu território de maneira radial, através de redes sociais extensas, guerras, alianças políticas, relações de parentescos, em busca de novas áreas de plantio e de novos recursos para manutenção do modo de ser Guarani (ñande rekó) (Noelli 1993; Soares 1997; Garlet 1997), consideramos possível que o sistema de assentamento serrano esteja articulado com o sistema litorâneo.

Na região litorânea, dois sítios arqueológicos Guarani foram datados: sítio PS-03-Totó, com datação radiocarbônica standard em 530 $\pm 40 \mathrm{AP}$, calibrada entre os anos 1390 a 1440 da Era Cristã ou (Beta Laboratory Inc. $n^{\circ}$ 237665). E o sítio PS-02-Camping, datado com a técnica de AMS em $380 \pm 50 \mathrm{AP}$, sendo a data calibrada colocada numa faixa temporal mais ampla, situada entre os anos 1450 a 1660 da Era Cristã (Beta Laboratory Inc., $n^{\circ}$ 234205). Estas datações indicam uma contemporaneidade de ocupação entre as duas áreas do sistema regional (serra e litoral), com uma diferença significativa no padrão de distribuição dos sítios arqueológicos.

Se na serra há um padrão formando um conjunto aglomerado de sítios arqueológicos, no litoral, por sua vez, o padrão de distribuição forma um alinhamento ao longo da margem da praia, com os sítios distando aproximadamente de 2 a $3 \mathrm{~km}$ entre si. Se no primeiro caso, o padrão de distribuição dos sítios arqueológicos está de acordo com o padrão de assentamento Guarani, na região litorânea, o padrão é diferenciado (disperso) e nos permite pensar que um processo de reconhecimento estaria sendo operado, numa região onde outros grupos culturais já dominavam. ${ }^{2}$ Estaria sendo desenvolvida uma primeira etapa de um processo de expansão territorial Guarani, um momento de reconhecimento do espaço e exploração de novos recursos. Um período de contatos culturais e anexação lenta e gradual do território tradicional (na serra), em que novas redes de relações sociais seriam estabelecidas em vias de ocupar este novo e promissor espaço (o litoral) (Brochado 1984; Noelli 1993; Soares 1997; Zedeño 1997, 2000; Garlet 1997; Milheira 2008a, 2008b).

\section{Os sítios arqueológicos e a indústria lítica}

Os sítios arqueológicos litorâneos caracterizam-se por aspectos distintos no que tange a sua função. Sabemos através de dados etno-históricos e etnográficos que no sistema de organização social e territorial Guarani, o espaço é ocupado de forma diferenciada, onde se articulam locais com funções distintas, desde a casa (oka), onde reside a família nuclear e/ou família extensa, a aldeia (amundá), o grupo de aldeias que articuladas por relações de parentesco e

(2) Esta região de lagoas e banhados em torno da laguna dos Patos é reconhecidamente um território de domínio dos grupos construtores de cerritos desde aproximadamente 2.435 \pm 85 A.P., até $200 \pm 80$ A.P. (Schmitz 1976). Fragmentos de cerâmica com decoração tipicamente Guarani são comumente encontrados em cerritos de toda região meridional da Laguna dos Patos, o que aponta para fenômenos de fronteira e relações inter-culturais entre estes grupos indígenas (Rogge 2004). 
alianças formam um território regional (teko’á) e o território Guarani em seu nível mais amplo, que configura uma espécie de nação (guará) (Noelli 1993; Assis 1996; Soares 1997).

O espaço que se caracteriza como um teko'á pode ser entendido como um conjunto de aldeias e acampamentos que formam então um território de domínio numa escala macro-espacial. ${ }^{3}$ Este espaço reconhecido e mapeado ao longo das gerações seria limitado por acidentes geográficos como rios, morros e cursos hídricos. Esses limites, além de serem definidos pelos aspectos simbólico-religiosos são também estabelecidos através das alianças políticas que determinam graus de prestígio e status social nas relações entre aldeias (Noelli 1993; Soares 1997). O teko'á poderia atingir, segundo Noelli (1993), um raio de $50 \mathrm{~km}$, sendo constituído por distintos ambientes que se caracterizam como eco-zonas, cuja interligação se daria através de caminhos e trilhas abertas na mata, assim como o uso de navegação fluvial e/ou marítima (Assis 1996). Estas eco-zonas interligadas constituem espaços de convívio e atuação cultural de diferentes escalas e funções como: aldeias, sítios para acampamentos de pesca, de caça, de coleta e as roças.

Em trabalho anterior (Milheira 2008a, 2008b) foi possível perceber a existência de dois tipos de sítios arqueológicos com funções distintas. A aldeia do Totó (sítio PS-03-Totó), onde foram identificadas estruturas arqueológicas de função funerária, habitacional, de combustão e de deposição de refugos. Na aldeia do Totó foi possível interpretar também, através do material cerâmico, contextos de ensino-aprendizagem e produção de artefatos, o que denota atividades sociais quotidianas típicas da vida aldeã. Neste sítio foram escavadas 60 sondagens; uma unidade de $2 \mathrm{~m}^{2}$ relativa a uma estrutura funerária. Escavou-se também uma unidade de $4 \mathrm{~m}^{2}$, referente a uma estrutura de deposição de refugos e combustão, composta

(3) Noelli (1993) e Assis (1996) traduzem o termo teko'á e tecoaba respectivamente por "estância". Neste caso, a aldeia está para a sede de um teko'á, assim como a casa grande está para a sede de uma estância. por uma camada de terra preta onde foram coletados 716 materiais cerâmicos, 139 materiais líticos, 172 vestígios arqueofaunísticos e 24 sementes de jerivá. A três metros ao lado, no sentido leste, foi escavada uma trincheira de $10 \mathrm{~m} \times 0,50 \mathrm{~m}$, com a coleta de 335 materiais cerâmicos, 20 artefatos líticos e 45 vestígios arqueofaunísticos, além de esteios e estacas que sugerem tratar-se de uma estrutura habitacional, cuja prática de limpeza doméstica incorreu no transporte de materiais para a estrutura de refugos ao lado (Milheira e Alves 2009). Este sítio, em termos de configuração do registro arqueológico, foi o que se mostrou mais denso, abrangendo uma área de aproximadamente $200 \mathrm{~m}$ de raio, com uma quantidade de materiais pelo menos 7,5 vezes maior que os demais sítios da região litorânea.

Quanto ao material lítico coletado nas intervenções arqueológicas, a coleção chama atenção não só pela sua quantidade superior, em comparação aos outros sítios litorâneos, mas também pela diversidade tipológica registrada. Foram analisados os materiais coletados nas sondagens, na unidade de escavação da estrutura de terra preta (estrutura de deposição de refugos) e da trincheira (onde ocorre a estrutura arquitetônica), o que soma um total de 165 peças líticas, sendo 63 lascas e fragmentos de lascas de calcedônia, quartzo e basalto, incluindo-se nesta soma: 4 raspadores, 10 furadores, 1 raspador/furador. Além disso, foram identificados também 92 instrumentos, sendo 41 aretafatos brutos, em sua maioria de arenito friável, 22 afiadores em canaleta ${ }^{4}$ de arenito friável, 18 alisadores em arenito friável e quartzo, 7 afiadores/alisadores 2 lâminas de machado fragmentadas de basalto, 2 percutores e também 10 núcleos.

(4) O termo "afiador em canaleta" refere-se aos instrumentos comumente descritos na literatura como placas de arenito friável ou cerâmica com sulcos nas suas faces, os quais indicam a confecção de pontas de projétil, furadores, punções, ou, até mesmo, adornos labiais (tembetás) (cf. Noelli 1993). Em nosso trabalho, porém, iremos ponderar a relaçãpo direta entre estes instrumentos com sulcos e a funçao de afiador, pois há a possibilidade de se tratarem de instrumentos usados para outros fins que não afiar. 


\begin{tabular}{|c|c|c|c|c|c|c|c|c|c|}
\hline Tipologia & Quant. & $\%$ & & Mat & éria- & rima & & $\begin{array}{c}\text { Medições } \\
\text { Médias }\end{array}$ & \\
\hline lascas & & & 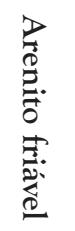 & 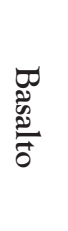 & 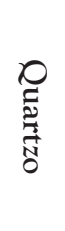 & 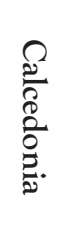 & $\begin{array}{l}0 \\
0 \\
0 \\
0 \\
0 \\
0 \\
0 \\
0\end{array}$ & 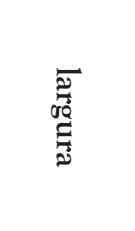 & 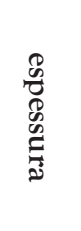 \\
\hline lascas com córtex & 5 & $8 \%$ & 0 & 0 & 0 & 5 & 2,7 & 2,04 & 0,9 \\
\hline lâmina & 8 & $13 \%$ & 0 & 0 & 0 & 8 & 3,2 & 1,1 & 0,3 \\
\hline lamela & 7 & $11 \%$ & 0 & 0 & 0 & 7 & 2,5 & 1,4 & 0,4 \\
\hline estilha & 15 & $24 \%$ & 0 & 0 & 0 & 15 & 1,5 & 0,69 & 0,2 \\
\hline lascas e estilhas & 18 & $28 \%$ & 0 & 0 & 8 & 10 & 2,6 & 1,75 & 0,67 \\
\hline fragmentos de lascas & 10 & $16 \%$ & 1 & 1 & 0 & 8 & $\mathrm{x}$ & $\mathrm{x}$ & $\mathrm{x}$ \\
\hline Total & 63 & $100 \%$ & 1 & 1 & 8 & 53 & $\mathrm{x}$ & $\mathrm{x}$ & $\mathrm{x}$ \\
\hline instrumentos & quant. & $\%$ & $\mathrm{AF}$ & B & Q & Cal & comp. & larg. & esp. \\
\hline percutor & 2 & $2 \%$ & 0 & 0 & 1 & 1 & 5,9 & 5 & 2,4 \\
\hline artefato bruto sem marcas de uso & 41 & $35 \%$ & 33 & 2 & 6 & 0 & 2,8 & 1,9 & 1,1 \\
\hline raspadores & 4 & $4 \%$ & 0 & 0 & 0 & 4 & 3,5 & 1,8 & 0,6 \\
\hline raspador/furador & 1 & $1 \%$ & 0 & 0 & 0 & 1 & 4 & 1,2 & 0,5 \\
\hline furadores & 10 & $9 \%$ & 0 & 0 & 1 & 9 & 2,3 & 1 & 0,3 \\
\hline frag. de machado polido & 2 & $2 \%$ & 0 & 2 & 0 & 0 & $\mathrm{x}$ & $\mathrm{x}$ & $\mathrm{x}$ \\
\hline afiadores em canaleta & 22 & $25 \%$ & 22 & 0 & 0 & 0 & 5,3 & 3,3 & 1,6 \\
\hline afiador/alisador & 7 & $6 \%$ & 7 & 0 & 0 & 0 & & & \\
\hline alisadores & 18 & $16 \%$ & 12 & 0 & 6 & 0 & 3,6 & 2,7 & 1,3 \\
\hline total & 107 & $100 \%$ & 74 & 4 & 14 & 15 & $\mathrm{x}$ & $\mathrm{x}$ & $\mathrm{x}$ \\
\hline Núcleos & quant. & $\%$ & $\mathrm{AF}$ & B & Q & Cal & comp. & larg. & esp. \\
\hline núcleo unipolar bidirecional & 1 & $10 \%$ & 0 & 0 & 0 & 1 & 3,9 & 3,2 & 1,1 \\
\hline núcleo bipolar & 9 & $90 \%$ & 0 & 0 & 0 & 9 & 3 & 2 & 1,9 \\
\hline total & 10 & $100 \%$ & 0 & 0 & 0 & 10 & $\mathrm{x}$ & $\mathrm{x}$ & $\mathrm{x}$ \\
\hline
\end{tabular}

Tabela 1. Quantificação geral dos materiais líticos do sítio PS-03-Totó

O outro tipo de sítio identificado refere-se aos sítios-acampamento (tapýi), ${ }^{5}$ categoria esta

(5) Conforme Novaes (1983), Noelli (1993) e Assis (1996), estes acampamentos se localizam geralmente às margens dos rios, córregos e lagoas, paisagens naturais da maior importância para a economia Guarani. Durante todo ano ou em períodos sazonais, grupos de pessoas de uma ou mais aldeias deslocam-se de suas residências e acampam às margens dessas áreas de assentamento para exploração desses recursos. Nos acampamentos constroem em que se enquadram os sítios PT-01-Sotéia, PT-05-Lagoinha e PS-02-Camping. Estes se carac-

estruturas necessárias ao convívio quotidiano e utilizam instrumentos para o abate, manipulação, armazenamento e transporte dos alimentos, sendo as estruturas arquitetônicas muito simples, geralmente caracterizadas por choças de palha e tronco verticais, que servem apenas para um abrigo temporário, tanto de pessoas como de equipamentos e alimentos 
terizam pela ausência de estruturas arqueológicas que indiquem uma ocupação permanente, tendo uma dimensão espacial muito inferior à aldeia do Totó, não ultrapassando um raio de 100 m. São localizados próximos da aldeia, mas com uma densidade de materiais muito inferior à mesma.

Sítio PT-01-Sotéia: O material lítico do sítio Sotéia é bastante simples no que se refere às tipologias. Apenas 27 artefatos líticos foram identificados nas coletas de superfície realizadas em três campanhas diferentes, sendo 11 artefatos brutos de quartzo, um alisador em arenito friável e um artefato multifuncional utilizado como lâmina de machado, alisador e afiador em canaleta, feito em basalto. Além disso, foram identificadas duas micro lascas (uma de calcedônia e uma de quartzo), três lascas unipolares (uma de quartzo, uma de basalto e uma de arenito silicificado) e oito fragmentos de lasca (uma de basalto, três de arenito silicificado e quatro de quartzo). $O$ restante dos materiais não apresenta qualquer tipo de traço de uso, logo, foram definidos apenas como instrumentos brutos, que nada mais são do que matéria-prima de quartzo em bloco, sem marcas de lascamento ou polimento.

Sítio PT-05-Lagoinha: O material lítico do sítio Lagoinha restringe-se a apenas três peças que foram coletadas em superfície, sendo dois artefatos modificados com marcas de uso: um bloco de quartzo com depressão semiesférica (quebra-coquinho) e marcas de queima; e um bloco de quartzo com marcas de debitagem, traços de esmagamento que indicam uso como percutor e marcas que sugerem também uso como bigorna. A outra peça sem marcas de utilização foi interpretada como descarte de matéria-prima de quartzo em bloco.

Sítio PS-02-camping: O material lítico do Camping também é bastante limitado em quantidade. Embora tenha sido realizada uma série de sondagens e escavação de duas unidades, tendo sido evidenciadas uma estrutura de deposição de refugos e uma estrutura de combustão, apenas cinco peças (todas de quartzo) foram coletadas e analisadas, sendo dois fragmentos de lascas, duas lascas unipolares e uma micro lasca.

\section{Proposta de análise. O estudo comparativo e as discussões}

O material lítico dos sítios arqueológicos identificados na região de pesquisa foi primeiramente estudado com o objetivo principal de gerar dados para reflexão sobre as dimensões do teko'á. Entendemos as "pedras" como um suporte para pensar as questões de territorialidade, visto que interpretamos a presença de peças líticas no litoral como um indicador de relação entre a região serrana e litorânea. Utilizamos como base para essa discussão os trabalhos de Noelli (1993, 1997), em que o autor discute, a partir de uma perspectiva etnoarqueológica, a dimensão espacial mínima do teko'á do Arroio do Conde.

Num esquema metodológico bastante simples e eficaz, o autor primeiramente identificou os materiais orgânicos e inorgânicos ausentes nas proximidades do sítio do Arroio do Conde, localizado no delta do vale do Jacuí. Logo em seguida, professou à identificação desses recursos num mapa geológico para os recursos inorgânicos como rochas e argila e, a estudos fitogeográficos para identificação de áreas com disponibilidade para determinados tipos de solos agriculturáveis e plantas. Conseguiu determinar, desta forma, que a distância entre o centro do assentamento e as fontes de recursos pode constituir um dado indicativo da dimensão espacial de um teko'á, cujo raio de ação atingiria até $50 \mathrm{~km}$.

Consideramos esta proposta metodológica bastante interessante para iniciar uma discussão sobre as dimensões do teko'á do Arroio Pelotas. Compreendemos que as fontes de recursos são estrategicamente mapeadas paulatinamente ao longo das gerações e que a localidade de cada uma dessas fontes faz parte do território de domínio Guarani. Podemos pensar, conforme Zedeño (2000), numa "cartografia comportamental”, termo esse que se refere à história de vida de um território, em que lugares e recursos são incorporados à vida social numa estrutura de longa duração. Do ponto de vista arqueológico, é importante tentar compreender a sequência de interações destes locais que: 1) transformam o lugar e os recursos localizados numa categoria 
de cultura material, como marcas históricas na paisagem e 2) ligam as marcas isoladas na paisagem numa rede funcional integrada que configura uma paisagem cultural.

Através do mapeamento das fontes de matéria-prima lítica, podemos conduzir a discussão para os aspectos sociais e tecnológicos da presença desse tipo de rocha em sítios do litoral. Pois, na medida em que esses recursos são ausentes no ambiente litorâneo, é possível considerar que o material lítico seja um indicador de relação entre, de um lado, as terras altas da serra e mesmo além destas; e, de outro lado, as terras baixas do litoral. Nesse caso, o material lítico é um suporte importante que não apenas confirma ou reforça os dados gerados pela análise da cerâmica, mas, pelo contrário, é uma fonte documental que amplia o escopo da pesquisa, trazendo à luz dados empíricos que permitem abordar a questão da estratégia de assentamento Guarani, domínio de território, ampliação de território para áreas não tradicionais, relações de prestígio e captação de recursos.

Num segundo momento, partimos a uma análise tecnológica das indústrias líticas dos sítios do litoral em vias não somente de identificar as suas características tecno-tipológicas, mas também compreender a cadeia operacional de produção dos instrumentos. Buscamos identificar a sequência operacional que envolve a obtenção e transporte de matéria-prima, manufatura dos instrumentos, uso, descarte e reciclagem dos mesmos, o que configura o ciclo de vida dos objetos (Schiffer 1972, 1987). Este encadeamento de ações e gestos técnicos evidencia um planejamento cognitivo individual e coletivo que atinge a esfera social em várias dimensões (Fogaça 2006). Conforme Luz \& Faccio (2006), no enfoque tecnológico os instrumentos são entendidos como objeto final de algum modelo mental, feito de acordo com uma forma pré-determinada. Logo, é importante identificar cronologicamente as ações da sequência operacional visando responder às seguintes perguntas sobre a indústria lítica: por que foi feito determinado instrumento? Como foi feito? Qual o resultado final do material produzido?

Colocadas as questões teóricas, os dados e os objetivos de nosso estudo, cabe aqui uma breve descrição da sistemática de análise dos materiais.
Os conjuntos líticos foram analisados a partir de quatorze categorias, divididas em seis amplas categorias que envolvem: Técnica de lascamento e Tipo de lasca, Tipo de Núcleo, Tipo de instrumento, Modificações, Suporte e Matéria-prima.

A análise sistêmica da cadeia operatória seguiu o esquema apresentado por Dias \& Hoeltz (1997), em que uma ampla descrição dos atributos é apresentada. Neste trabalho, as autoras demonstram as diferentes técnicas de lascamento e polimento relativo às ações do artesão (no contexto cultural), evidentes através do padrão tecnológico dos artefatos e do padrão de descarte no sítio (no contexto arqueológico). Para descrição dos artefatos e definição das categorias funcionais nos utilizamos também dos trabalhos de Prous (1986/1990), Morais (2007) e Mello e Viana (2001), os quais se mostraram bastante elucidativos e didáticos. Foi importante também consultar o trabalho de Noelli (1993) e Noelli \& Dias (1995), autores que objetivaram buscar nos dados etno-históricos as terminologias linguísticas das categorias funcionais líticas correntes entre os Guaranis para então comparar e aplicar estas categorias aos artefatos identificados no contexto arqueológico. Com isso, os autores procuraram ir além da descritividade formal tão tradicional em arqueologia, gerando não apenas um esquema metodológico que articula diferentes tipos de informações (etno-históricas, etnográficas e arqueológicas), mas, também, tentando aproximar as categorias funcionais das categorias êmicas Guarani, recorrentes numa estrutura histórica e cultural de longa duração.

Foi fundamental também realizar atividades de experimentação. O lascamento de geodos de calcedônia através de técnica de percussão direta unipolar e com técnica bipolar permitiu classificar as lascas e demais instrumentos em suas diferenças morfológicas e técnicas. O lascamento bipolar, aliás, tem sido uma técnica pouco discutida na literatura arqueológica, sendo uma incógnita se pensarmos na literatura sobre os materiais líticos Guarani.

1) Como primeiro item da análise temos as lascas que são interpretadas como resquícios de produção de instrumentos, bem como instrumentos em si, pois servem para cortar, 
furar, raspar pequenas superfícies, etc.. No que se refere à técnica de lascamento, predomina o lascamento bipolar em detrimento dos poucos vestígios unipolares, tendo sido identificados os seguintes tipos de lascas: lascas com presença de córtex, lascas sem córtex, lâminas, lamelas, estilhas e fragmentos de lasca.

2) Os núcleos correspondem à massa de matéria-prima resultante do processo de lascamento, podendo ou não ser explorado até sua exaustão e posteriormente descartado. Identificamos dois tipos de núcleos: núcleo bipolar e núcleo unipolar bidirecional.

3) Os instrumentos são confeccionados através de polimento ou lascamento. São peças que servem no uso quotidiano como ferramentas para roça, construção de estruturas arquitetônicas, bem como para cortar, bater, polir, afiar, furar, moer, etc.. São divididos em lâminas de machado polido, afiadores em canaleta, alisadores, raspadores, percutor, furadores, instrumentos multifuncionais, (quando mais de uma atividade funcional é percebida na peça) e artefatos brutos (aqueles que mantêm a forma bruta e que não têm nenhuma marca de modificação). A função dos artefatos é indicada primeiramente pela morfologia das peças, complementada e problematizada através dos macro traços de uso, visíveis a olho nu. Em seguida, realizamos também a análise dos artefatos com o uso de lupa trilnocular, que segundo Mansur (1986/90 apud Dias \& Hoeltz 1997), possibilita uma análise funcional mais segura (low approach).

4) As modificações são indicadores de atividades de desbaste, desgaste, quebra ou uso das pedras como "pedra de fogo". São percebidas alterações térmicas, marcas de uso e retoques;

5) Suporte é base em que a lasca ou o instrumento foi confeccionado e constitui um indicador importante para definir se a rocha utilizada foi retirada de sua fonte original (afloramento) ou de uma cascalheira localizada em margem de algum tipo de curso hídrico. Os tipos de suporte são blocos, lascas, geodos, placas e seixos.

6) As matérias-primas identificadas são registradas na região do Escudo Sul-rio-grandense (Pré-Cambriano), na região da Depressão Periférica e no Planalto da Serra Geral. Em linhas gerais, podemos dizer que as fontes de matéria-prima utiliza- das pelos grupos Guarani podem distar de 30 até $200 \mathrm{Km}$ da planície costeira. As matérias-primas identificadas foram: granito, calcedônia, quartzo, basalto, arenito silicificado e arenito friável.

\section{Em busca da cadeia operatória}

\section{A obtenção da matéria-prima}

Através de um mapeamento de fontes de matéria-prima realizado a partir do Mapa Geológico do Estado do Rio Grande do Sul foi possível delimitar localidades em que ocorrem afloramentos rochosos de quartzo, granito, arenito friável, arenito silicificado e basalto. Bem como, áreas de ocorrência de geodos de calcedônia em meio a afloramento de arenito friável.

Essas áreas, fontes de matéria-prima são aqui tratadas como localidades que possivelmente os grupos Guarani tenham explorado, evidenciando um domínio de território bastante amplo, em que se articulam ambientes distintos. O mapeamento das fontes de matéria-prima seria um passo inicial dos grupos na aquisição de novos territórios, bem como indica a primeira etapa da cadeia operatória: a escolha, obtenção, transporte e/ou troca de suportes líticos para incorrer na manufatura de artefatos através de lascamento ou polimento. Em nossa análise, sugerimos que os suportes tenham sido transportados até a localização dos sítios sem haver preparo antecipado, sendo, portanto, toda cadeia de confecção dos artefatos desenvolvida nos locais de moradia. Na imagem abaixo, apresentamos o Mapa Geológico com a indicação das fontes de matéria-prima com as respectivas distâncias entre estas e a área central do assentamento Guarani na porção litorânea. Cada área tem uma descrição geológica sintética que visa apresentar as suas características principais e as cidades mais conhecidas onde se localiza.

\subsection{Descrição das áreas/fontes de matérias- primas líticas}

Área 1: localiza-se no município de Jaguarão, na região do Escudo Sul-rio-grandense, de idade Pré-Cambriana, numa zona de ocor- 


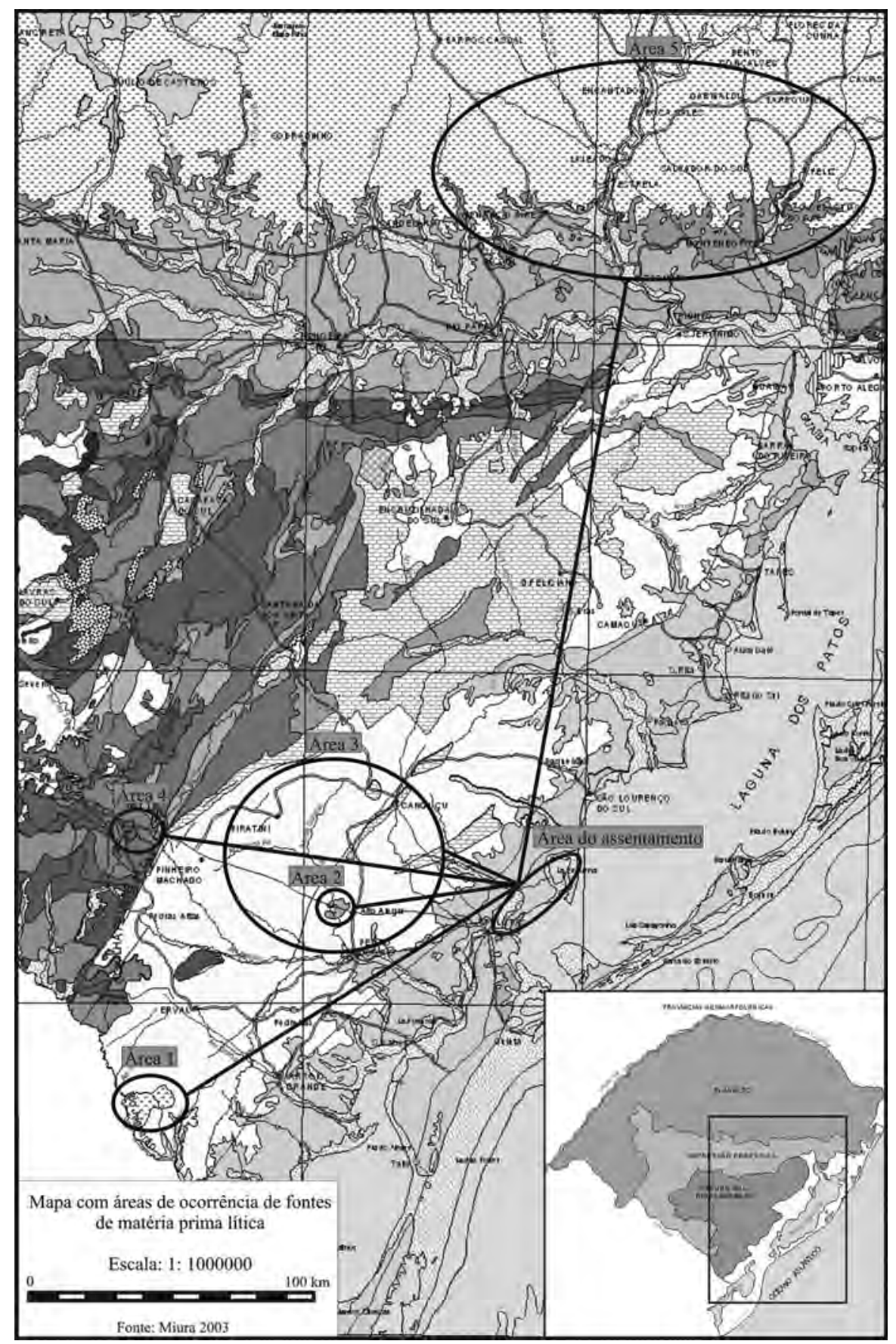

Fig. 2. Mapa Geológico com a indicação das fontes de matéria-prima com as respectivas distâncias entre estas e a área central do assentamento Guarani na porção litorânea.

rência de limites transformantes, relacionados a abertura do Oceano Atlântico, onde se deu uma intrusão de basalto de coloração escura.
Esse basalto, de idade Mezosóica, intrudiu a região do Escudo Sul-rio-grandense (Pré-Cambriano). A área 1 dista aproximadamente 
$120 \mathrm{~km}$ do centro do assentamento Guarani no litoral.

Área 2: localiza-se entre os municípios de Piratini, Pedro Osório e Cerrito, também na região do Escudo Sul-rio-grandense, numa zona de ocorrência de arenitos quartzosos originados anteriormente à formação do Escudo Cristalino. A área 2 dista aproximadamente $65 \mathrm{~km}$ do centro do assentamento Guarani no litoral.

Área 3: são rochas do Escudo Sul-rio-grandense, localizadas em municípios como Piratini, Pinheiro Machado, Pedro Osório, Canguçu, Cerrito, Capão do Leão e o interior do município de Pelotas, onde também se encontram as áreas do assentamento Guarani da serra. No Escudo ocorrem rochas graníticas e subordinadamente metamórficas e sedimentares; presença de falhas preenchidas com quartzo leitoso. A área 3 dista aproximadamente $30 \mathrm{~km}$ do centro do assentamento Guarani no litoral.

Área 4: localiza-se nos município de Candiota, Bagé e Aceguá, no limite entre a Depressão Periférica e o Escudo Sul-rio-grandense, onde se acham afloramentos de folhelhos, arenito e conglomerados friáveis com presença de seixos de geodos de calcedônia associados. A área 4 dista aproximadamente $130 \mathrm{~km}$ do centro do assentamento Guarani no litoral.

Área 5: localiza-se na região de municípios como Lajeado, Taquari, Sapucaia do Sul, São Leopoldo e Caxias do Sul. Essa área compreende o limite meridional entre o Planalto da Serra Geral e a Depressão Periférica; onde se aí se localizam rochas do tipo: arenito friável feldspático, arenito silicificado, basalto acinzentado claro ${ }^{6}$ e geodos de calcedônia associados a formações de basalto. A área 5 dista aproximadamente $200 \mathrm{~km}$ do centro do assentamento Guarani no litoral.

(6) O basalto que identificamos nos instrumentos dos sítios arqueológicos Guarani, tanto do litoral como da serra, são de coloração acinzentado claro, o que é um indicador que os grupos explorassem as fontes de basalto da região o Planalto da Serra Geral (área 5), ao invés das fontes de basalto, de coloração escura, similares aos da região de Jaguarão (área 1).

\section{A manipulação das matérias-primas: manu-} fatura, uso e padrões de descarte

\subsection{A cadeia operatória de uso da calcedônia}

Através da análise tecnológica das lascas e núcleos de calcedônia, presentes no contexto arqueológico do sítio PS-03-Totó, podemos considerar que houve um esforço acentuado na manutenção desta matéria-prima, devido ao difícil acesso às suas fontes que distam em torno de 130 a $200 \mathrm{~km}$. Do ponto de vista estratégico, estas distâncias implicaram em um manuseio adequado e cauteloso da calcedônia, não sendo esperado o desperdício de matéria-prima.

Notamos que houve a intenção em produzir lascas bipolares finas, pois, a média de espessura das 53 lascas e estilhas analisadas é de apenas $0,4 \mathrm{~cm}$. Este dado indica que houve um aprimoramento tecnológico importante para a manufatura de instrumentos em calcedônia. Sugerimos que o lascamento realizado tenha sido desenvolvido com um controle apurado da técnica bipolar, permitindo um amplo controle da debitagem e, por conseguinte, gerando um desperdício menor de matéria-prima.

\subsection{Núcleos}

Os núcleos são blocos de matéria-prima que serviram como suporte para retirada de lascas, suportes estes que eram obtidos a partir de pequenos e médios geodos de calcedônia com comprimento entre 1,9 e $6,2 \mathrm{~cm}$; largura entre 0,7 e $5 \mathrm{~cm}$; espessura entre 0,3 e $2,4 \mathrm{~cm}$. A matéria-prima dos núcleos apresenta características heterogêneas, com variação na coloração, mas sem diferenças significativas na textura e tenacidade. Houve a tentativa frustrada em remontagem dos núcleos para que pudéssemos projetar a sequência de lascamento com maior precisão.

Analisamos dez núcleos, sendo nove deles bipolares e apenas um unipolar, diferenciados pela morfologia e pelas cicatrizes de lascamento.

Os núcleos bipolares, em quantidade de nove peças, apresentam-se sem a presença 
de córtex, sem bulbo e talão preparado. As lascas, retiradas em sentidos opostos, geram negativos que não podem ser medidos com segurança, devido ao fato de que a técnica bipolar gera muitas lascas fragmentadas. Sugerimos que o processo de lascamento bipolar tenha se dado com uso de bigorna, pois, em todos os casos notamos que a porção distal dos núcleos (que teria contato com a bigorna) encontra-se fragmentada de maneira irregular, indicando que vários impactos teriam sido desferidos sobre o suporte, gerando a fragmentação ao nível mesial em dois casos.

O núcleo unipolar bidirecional caracteriza-se pela retirada de lascas em sentidos opostos, com plano de percussão visível em apenas uma das extremidades. Os negativos de lascas variam entre 0,9 e $4,5 \mathrm{~cm}$ de comprimento e 0,5 e 2,9 cm de largura. O núcleo, com formato piramidal, demonstrou um processo de lascamento circular, em que os negativos de lascas sobrepõem-se na intenção da preparação do suporte para um lascamento central, quando é então retirada uma lasca com formato lanceolado utilizada posteriormente como raspador (como veremos a seguir).

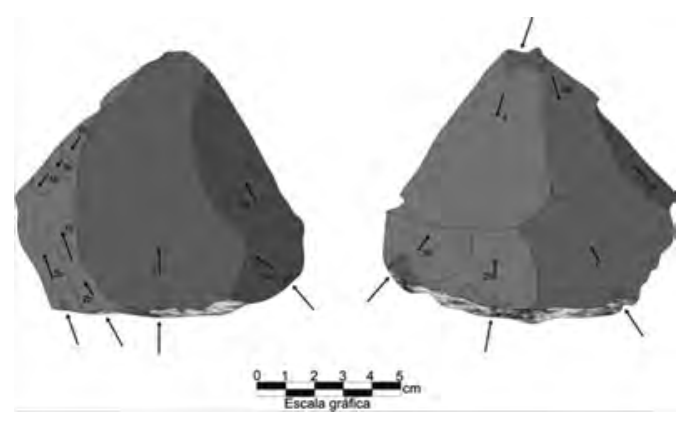

Fig. 3. Esquema diacrítico de um núcleo bidirecional de calcedônia. Exemplo de um processo de lascamento circular em sentido horário, com golpes disferidos, por um lado, a partir de um plano de percussão cortical preparado e, por outro lado, com golpes opostos, num plano acortical também preparado. Fica evidente a preparação do núcleo piramidal através de lascas finas de pequeno e médio porte para posterior debitagem de lascas centrais com formato lanceolado passíveis de serem usadas como raspadores.

\subsection{Lascas}

O estudo das lascas e núcleos nos permitiu traçar uma cronologia de lascamento que segue a seguinte lógica.

Lascas com córtex: Como resultado inicial de abertura dos geodos, o lascamento bipolar gera uma série de lascas com córtex na superfície externa. Estas lascas medem entre 2 e 4,2 cm de comprimento, 1,7 e 2,8 cm de largura e 0,4 e 1,4 cm de espessura. Em nossa coleção, identificamos este tipo de lascas com córtex presente entre $25 \%$ e $100 \%$ da porção dorsal das mesmas. Após a debitagem, as lascas corticais teriam sido então descartadas, em decorrência de seu baixo valor funcional, pois não foram notadas marcas de retoque ou uso posterior em sua maioria, com exceção de apenas uma lasca que apresentou retoques na sua porção distal.

Lascas bipolares: Este tipo de lasca apresenta medidas entre 1,5 e $4,7 \mathrm{~cm}$ de comprimento, 0,6 e 1,9 cm de largura e $0,4 \mathrm{~cm}$ de espessura. Caracterizam-se geralmente por serem lascas sem marcas de bulbo e talão, com seu perfil reto devido à técnica empregada que gera dois pontos de impacto opostos.

Lâminas e lamelas: o interesse maior no processo de lascamento da calcedônia parece ter sido a produção de determinados tipos de lascas descritas na literatura (Prous 1986/1990; Morais 2007) como lâminas (lascas alongadas que apresentam uma relação de comprimento maior que duas vezes a largura) e lamelas (lascas alongadas de pequena espessura e tamanho, que apresentam uma relação de comprimento menor ou igual a duas vezes a largura). Entre as lâminas, algumas apresentam uma das extremidades mais apontada, outras mais lanceoladas, características estas em que nos baseamos para uma classificação funcional diferenciada, que foi confirmada pela visualização dos traços de uso em lupa. Estas lascas seriam resultantes de um lascamento bipolar, com a retirada de lascas finas e alongadas.

Aquelas lascas com formato lanceolado poderiam ser usadas para raspar (hey̆î, añâpepĭ e añôpŭ) ou "remover superfícies, durante o processo de confecção de algum bem ou na elaboração de alimentos, como por exemplo, 'raspar casca de 
mandioca' (...) 'desbastar madeira'” (Noelli 1993: 215). Estes instrumentos usados para raspar, produzidos sobre lascas seriam denominados de pepŷ hába, havendo um instrumento específico para confecção de anzóis cujo nome seria pŷndá ba (Noelli op cit). Outras funções possíveis destas lascas seriam a ação de aplanar ou adelgaçar, conforme os verbos ñôĭ - aplanar e amboyỉbata iburrá ypinnâ "aplanar pau adelgaçado” e cortar, conforme o verbete quicé yta "pedra que corta" e amboyobite "cortar, partir pela metade seja o que for" (Noelli, op cit). Na lupa, estas lascas apresentam um micro lascamento causado pelo uso, disposto perpendicularmente ao eixo maior da lasca, indicando o bordo ativo.
Por outro lado, as lascas puntiformes poderiam ser usadas como furadores. Furar é um termo que aparece nos verbetes como aiqua boñã e, especialmente, aycutú "furar com punção". O ato de punçar "indica a função dos instrumentos ativos produzidos a partir de núcleos e lascas de diversas matérias-primas, principalmente as cristalizadas" (Noelli, 1993, p. 216). Em lupa estas lascas apresentam a extremidade distal fraturada ou com micro lascamento, marcas estas causadas pelo uso. Em alguns casos há um micro lascamento que avança na porção marginal da lasca, o que entendemos como traços do ato de furar e enfiar o instrumento até, pelo menos, um terço da lasca.
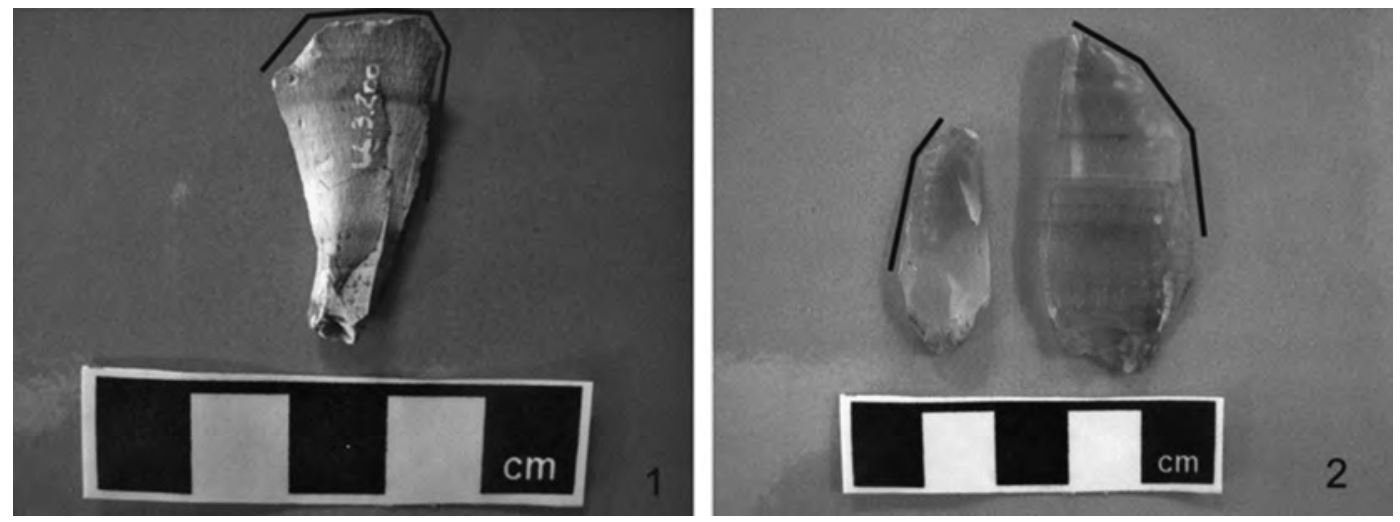

Figs. 4 e 5. Exemplares de raspadores em calcedônia do sítio PS-03-Totó. Lamela (nº cat. 66.3.200) com indicação do bordo ativo na extremidade distal e na sua porção marginal direita. Esta lamela chama atenção por ser ter sido confeccionada em osso fossilizado; (2) lâmina e lamela usadas como raspadores como bordo ativo marginal.
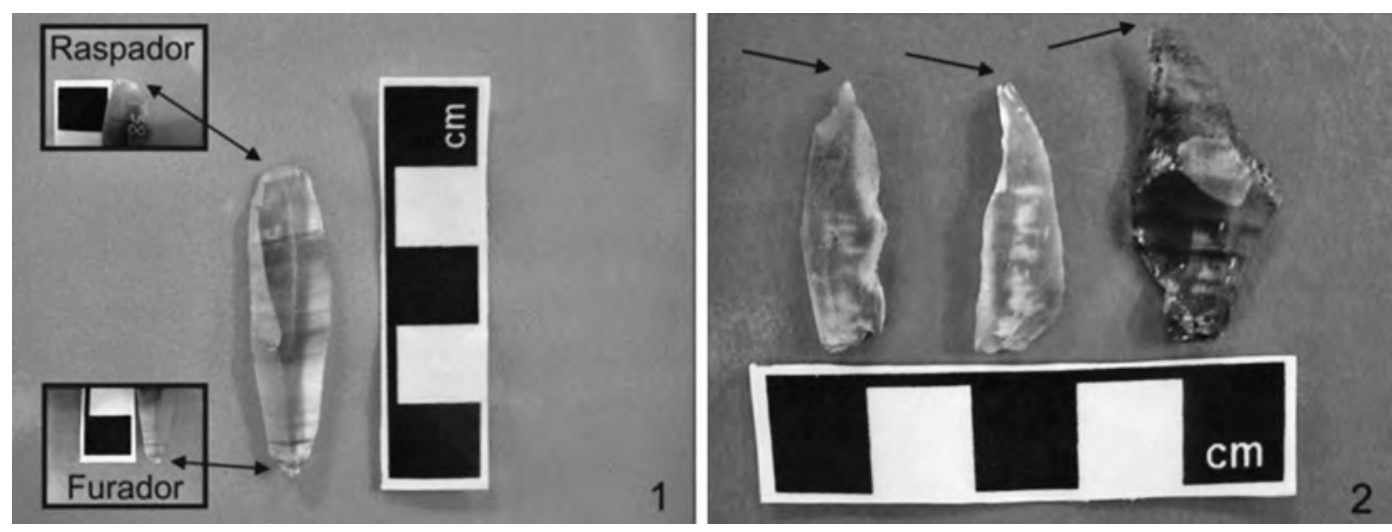

Figs. 6 e 7. Exemplares de furadores em calcedônia do sítio PS-03-Totó. (1) Lâmina (nº cat. 70.03.585) com marcas de uso em ambas as extremidades, indicando funcionalidade como raspador e furador; (2) lamela e lâminas usadas como furadores com marcas de uso na extremidade distal. 


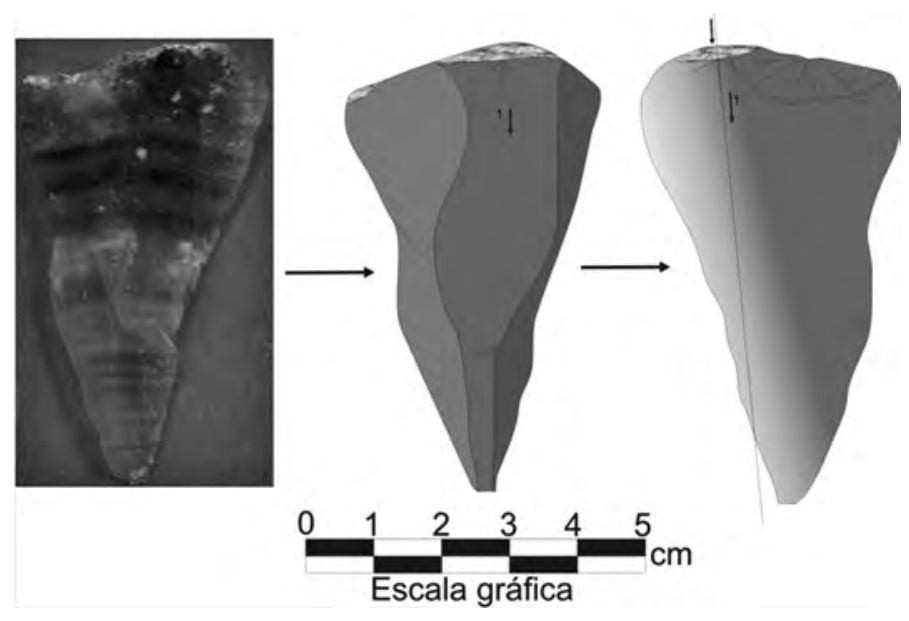

Fig. 8. foto e desenho de furador sobre lamela. Nota-se a fratura na extremidade distal causada pela ação de furar. Ver também a retirada 1 na posição dorsal, que permitiu afilamento da lasca, com retirada parcial do talão cortical, provavelmente para facilitar encabamento.

Uma das lamelas puntiformes apresenta também um lascamento inverso na altura do talão para adelgaçamento da peça na sua porção dorsal e para facilitar um possível encabamento. Pelo fato de esta peça ter uma espessura muito fina, parece improvável que tenha sido usada como ponta de projétil; mas provavelmente como furador encabado, embora a morfologia incite esta discussão.

Há um caso em que ambas as funções foram percebidas. A lasca 70.03.585 apresenta uma das extremidades com marcas de uso que indicam que a ferramenta tenha sido usada para furar. A outra extremidade, com micro lascamento perpendicular ao gume, sugere que a mesma peça tenha sido usada também para aplanar ou cortar, o que é corroborado pela análise dos gumes laterais da lasca que se encontram arredondados pelo uso intenso (ver figura 6 novamente).

\subsection{A cadeia operatória de uso do arenito friável}

Outra matéria-prima lítica de fundamental importância no sítio PS-03-Totó pela sua representatividade e pela variação funcional é o arenito friável. De forma semelhante à calcedônia, o arenito friável parece ter sido usado cautelosamente devido à dificuldade em obtenção deste tipo de matéria-prima que tem suas fontes distando em torno de $200 \mathrm{~km}$.

$\mathrm{Na}$ sequência operacional deste tipo de material, notamos que as placas de arenito são usadas passivamente, servindo em sua maioria como suporte para manufatura de outros tipos de instrumentos. Foi identificado no sítio Totó um total de 29 peças com sulcos espessos na superfície das placas de arenito (medições das peças com 2,1 e $10 \mathrm{~cm}$ de comprimento; $1,4 \mathrm{e}$ $4,8 \mathrm{~cm}$ de largura e 0,5 e 3,6 $\mathrm{cm}$ de espessura) e 18 peças em arenito com a superfície alisada (medições das peças com 1,7 e 6,3 cm de comprimento; 1,2 e 4,9 cm de largura e 0,5 e 3,3 cm de espessura), sugerindo tratar-se de alisadores. Três peças com marcas de queima sugerem o uso de placas de arenito como apoio de vasos cerâmicos que vão ao fogo. Os demais materiais em arenito friável não apresentam marcas de uso, sendo interpretados como placas fraturadas após sua exploração total em outras finalidades. Isto explicaria as pequenas dimensões destes materiais fragmentados, entre 1,3 e $9 \mathrm{~cm}$ de comprimento; 0,6 e $5,7 \mathrm{~cm}$ de largura e 0,3 e 5 $\mathrm{cm}$ de espessura.

É interessante notar a variação funcional do arenito friável, que segue uma sequência operacional bastante peculiar. Num primeiro momento, o interesse nessa matéria-prima parece ser em utilizá-la como "afiador" em canaleta que serviriam, conforme o verbo ahaymbee - "amolar", para "polir superfícies ou arestas com gume relativamente agudo e estreito, geralmente de ossos" (Noelli, op cit). Em nosso estudo, constatamos que as canaletas destes instrumentos não serviriam para afiar o gume dos machados, pois apresentam os sulcos em formato em "U". Caso fossem usados para afiar o gume dos machados deveriam apresentar um sulco em formato de "V". Sugerimos, nesse caso, que os "afiadores" servissem como suportes passivos para confec- 


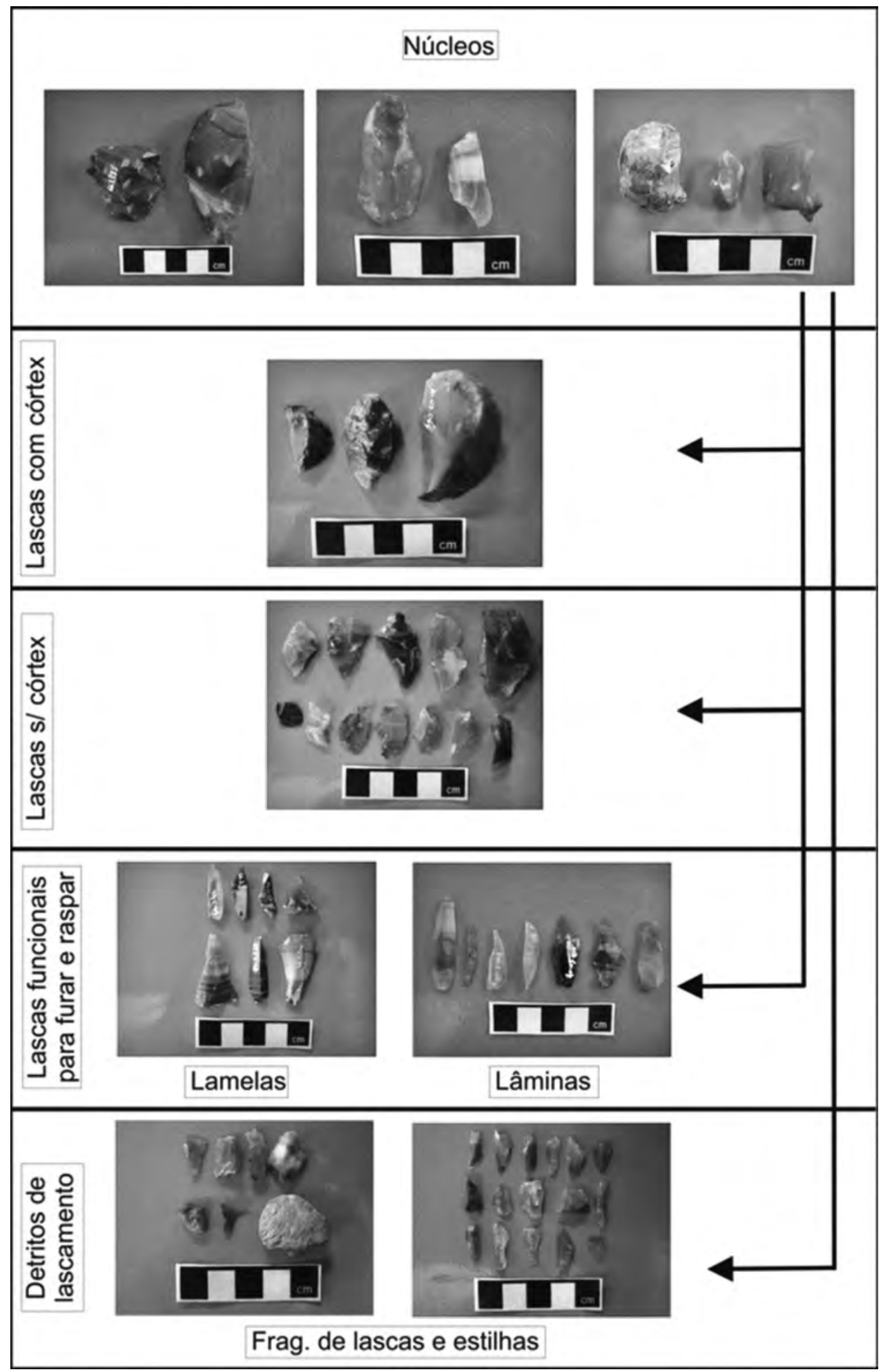

Fig. 9. Caracterização com fotos da cadeia operatória de uso da calcedônia. 

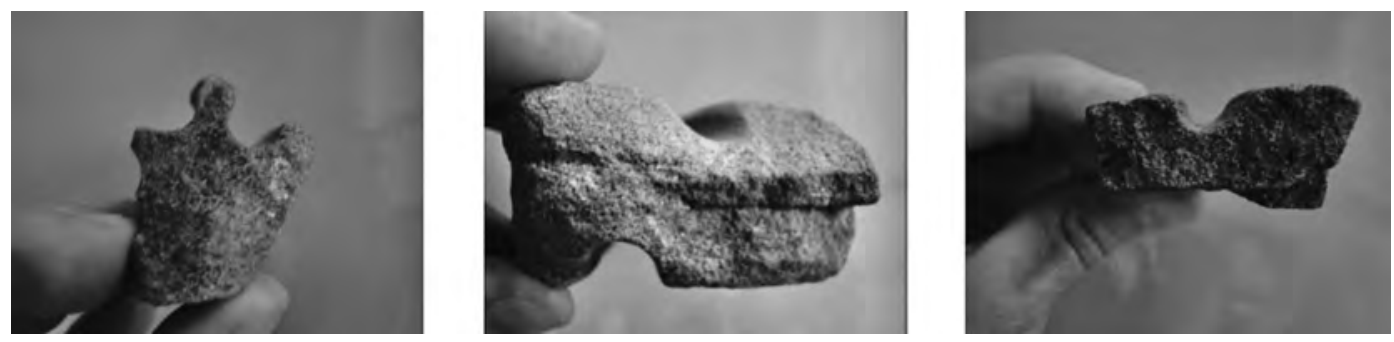

Figs. 10 a 12. formato em "U" das canaletas dos afiadores.

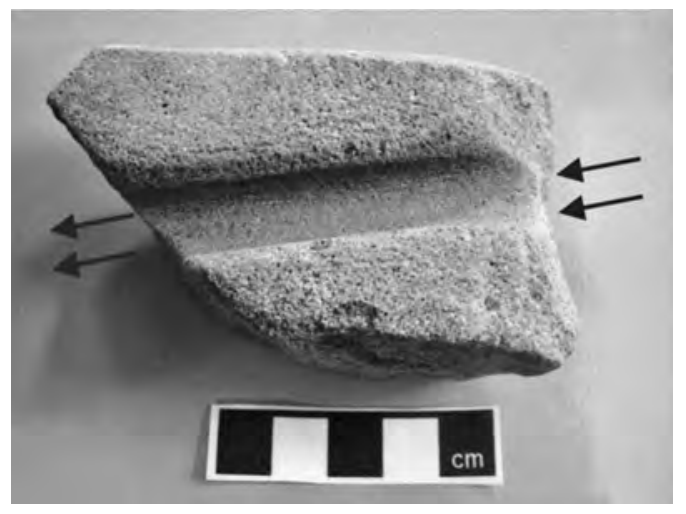

Fig. 13. indicação das estrias de polimento no sentido longitudinal da canaleta. Note-se também a superfície polida da peça, indicando a função de alisador.

ção de instrumentos, como por exemplo, hastes de flechas em madeira, instrumentos em ossos ou tembetás em rochas. A base para esta interpretação são as estrias de polimento no sentido longitudinal das canaletas facilmente visíveis em algumas das peças e, também, nas medições das espessuras que variam entre 0,7 e 1,3 cm (as mais grossas), que seriam para as hastes das flechas. Já os instrumentos com sulcos com espessuras entre 0,3 e 0,6 cm serviriam para outras funções como produção de tembetás e outros tipos de artefatos em madeira e osso.

Outro interesse nas placas de arenito seria utilizá-las como alisador, conforme o verbo añâpẽçŷ, que significa: "alisar com a intenção de regularizar superfícies", ou seja, "o ato de remover irregularidades de superfícies de madeira, de cerâmica, remover felpas, etc. (...) A expressão ymocŷmbíra constata que um objeto foi polido, brunido" (Noelli, op cit). Uma mesma placa de arenito pode ser usada também para ambas as finalidades, como é sugerido pela presença de sete instrumentos com sulcos de afiação e superfície alisada. Após a exploração das plaquetas de arenito por uma e/ou outra função, as mesmas eram refugadas na lixeira ou usadas como apoio de panelas, cujo verbete relativo é ytácurû.

Trata-se de pedras usadas sob certos vasilhames que iam ao fogo, como aqueles do tipo yapepó (panelas) ou ñaetá (caçarolas), bastante freqüentes na aldeia do Totó. Estas vasilhas usadas para cozimento de alimentos geralmente apresentam bases em formato conoidal ou globular, daí a necessidade de suportes para sustentação.

\subsection{A cadeia operatória de uso do quartzo}

O quartzo tem uma representatividade importante por ser muito presente enquanto matéria-prima explorada, com menor intensidade que a calcedônia e o arenito friável. Além disso, como pudemos ver nas coleções dos sítios litorâneos, o quartzo compõe basicamente a indústria lítica dos sítios-acampamento. Trata-se, em sua maioria, de blocos oriundos de veios que afloram no Escudo Cristalino da Serra do Sudeste. Sua coleta, portanto, ocorreu diretamente nas fontes cristalinas da serra. A sequência operacional do quartzo é muito simples em termos tecnológicos. Foram identificados instrumentos brutos como percutores para lascamento usados na debitagem de lascas de quartzo, calcedônia e basalto, indicando um entrecruzamento funcional entre os diferentes tipos de rochas.

Além de percutores, identificamos no sítio PT-05-Lagoinha, um bloco de quartzo com uma depressão semiesférica (quebra-coquinho) e marca de queima, usado como "pedra de fogo" (cujo verbete relativo é ytácurû) para o apoio de panelas e caçarolas. Também um bloco de quartzo com marcas de debitagem, traços de esmaga- 

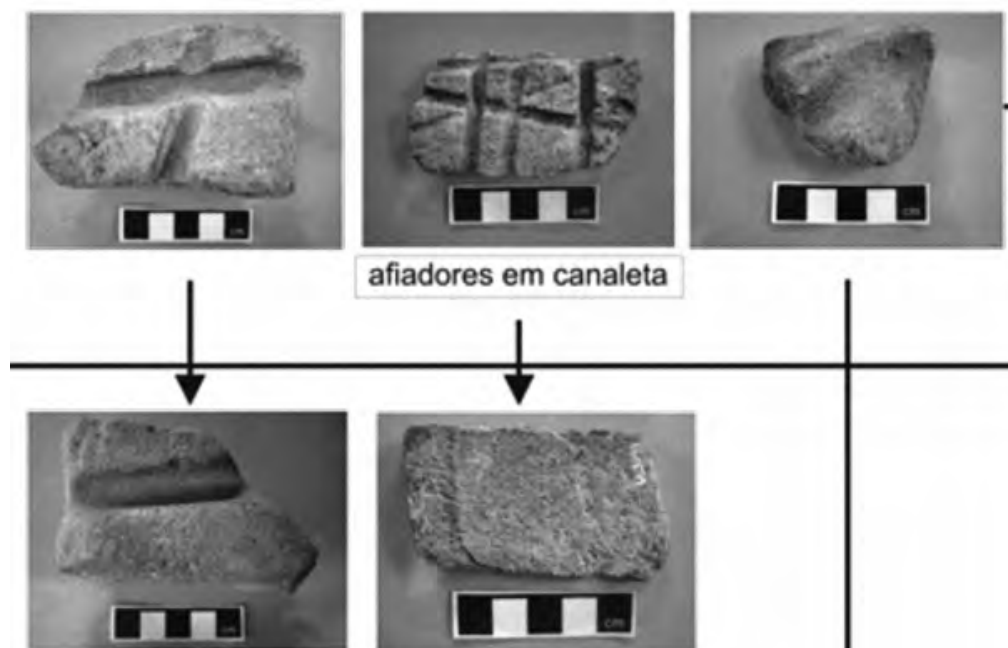

afiadores em canaleta
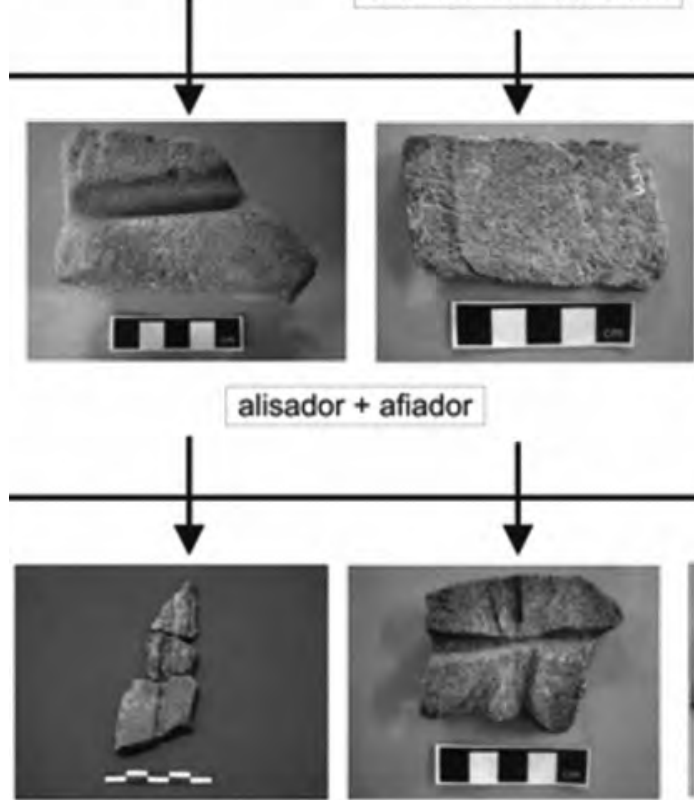

+ afiador

fragmentação e super-exploração de afiadores em canaleta

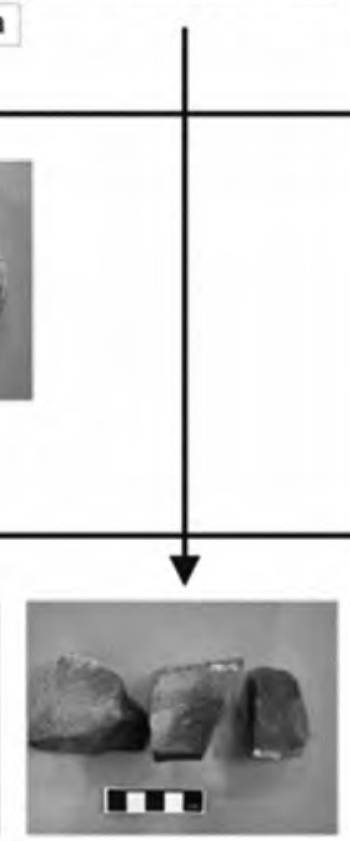

suportes ou "pedra de fogo"

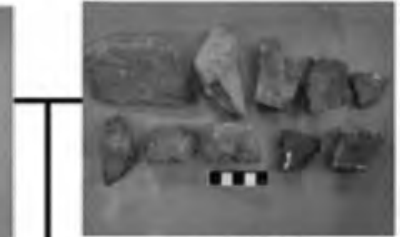

alisadores
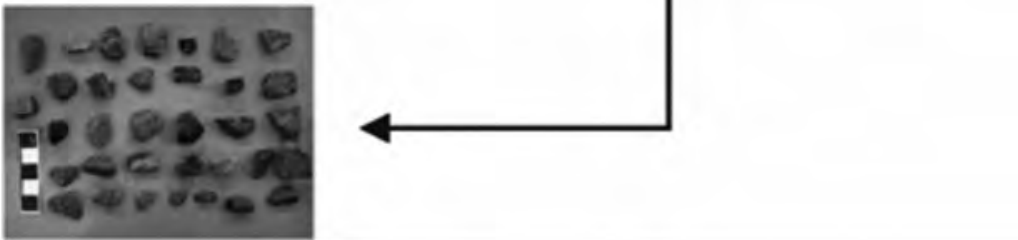

Fig. 14. Caracterização com fotos da cadeia operatória de uso do arenito friável.

mento nas arestas que indicam uso como percutor e marcas em formato de "vírgula" numa das superfícies que denotam que este bloco teria sido usado como apoio para lascamento bipolar (bigorna). Indicamos que esta peça tenha sido primeiramente utilizada como percutor e apoio para lascamento bipolar e, posteriormente, com as fraturas decorrentes de sua função primeira, usada como núcleo para retirada de algumas lascas unipolares.

A debitagem de quartzo é bastante limitada. Identificamos apenas lascas unipolares primá- 

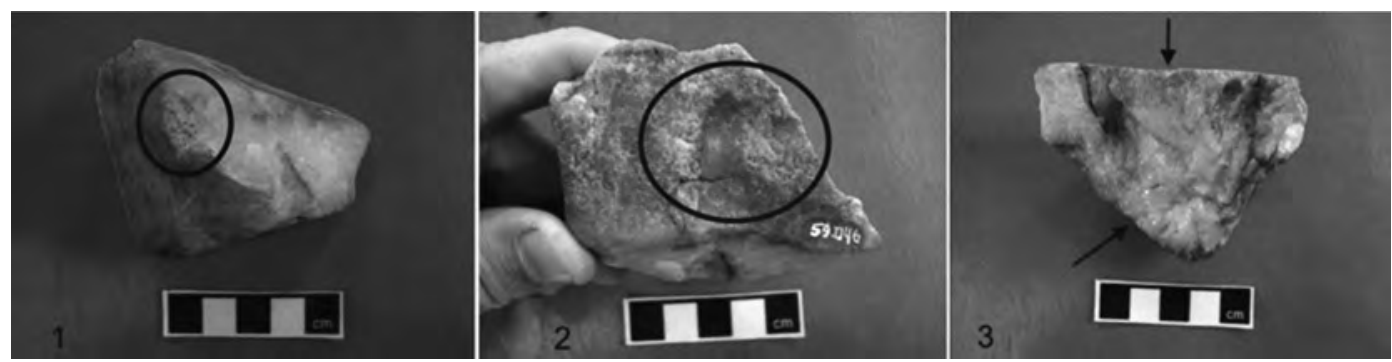

Figs. 15 a 17. Bloco de quartzo multifuncional: (1) esmagamento na superfície por uso como percutor, (2) marcas em "vírgula" como suporte de lascamento bipolar, (3) pontos de percussão por lascamento.

rias sem traços de uso e microlascas (resíduos de lascamento), geradas através de lascamento com percutor duro. Os núcleos unipolares multidirecionais com formato poliédrico apenas apresentam duas ou três retiradas marginais, sem indicação de um planejamento acentuado que buscasse a otimização do suporte em termos de quantidade e qualidade de lascas.

Blocos de quartzo sem modificações ou traços de uso, no entanto, compõem a maioria dos materiais líticos dessa matéria-prima identificados nos sítios arqueológicos. Sugerimos que esses blocos teriam sido usados apenas como pesos, escoras e aquecedores (Noelli 1993; Soares 2005), ou, nem sequer tivessem sido usados, sendo, neste caso, matéria-prima não manipulada e descartada. Ainda em quartzo, foram coletados cinco seixos de pequeno porte no sítio Totó que podem estar relacionados ao processo de manufatura de vasilhas cerâmicas. Estes pequenos seixos de superfície bastante alisada, são reconhecidos como instrumentos utilizados na etapa de alisamento da superfície cerâmica, permitindo, inclusive, dar a cerâmica um polimento brilhoso (Shepard 1985 [1956]). No mesmo sítio ocorreu um furador de quartzo com 1,6 cm de comprimento, $0,7 \mathrm{~cm}$ de largura e $0,6 \mathrm{~cm}$ de espessura.

No geral, exceto pelo furador descrito, não foram observados nos sítios litorâneos, tanto na aldeia do Totó como nos sítios-acampamento, tipos de materiais mais "elaborados" em termos tecnológicos. Se compararmos com a cadeia operatória da calcedônia e do arenito friável, o quartzo não parece representar uma cadeia operatória com um planejamento acentuado. Esta questão poder ser entendida pela facilidade em obtenção desta matéria-prima, o que dispensaria um tratamento muito acurado de otimização e exploração intensiva.

Distâncias e estratégias: discutindo obtenção, manufatura, uso e descarte de materiais líticos

A partir da análise espacial do mapa com as áreas de ocorrência de fontes de matéria- prima é possível tecer algumas interpretações que dizem respeito à exploração dessas fontes pelos grupos Guarani. A distância da área central do assentamento litorâneo para cada área de fonte de matéria-prima lítica varia entre $30 \mathrm{~km}$ e 200 $\mathrm{km}$, sendo, portanto, uma amplitude bastante significativa que alude a diferentes estratégias para obtenção destes recursos. Podemos pensar estas áreas de ocorrência de fontes de matéria-prima como zonas de influência, cujo domínio e exploração demandam um esforço estratégico que envolve redes sociais. Sugerimos que duas zonas de influência sejam possiveis: zonas de influência direta e zonas de influência indireta.

a) As Zonas de influência direta são aquelas ativa e diretamente exploradas, em que os grupos poderiam se deslocar para chegar às mesmas, sem que necessariamente houvesse relações sociais de troca com outros grupos, sejam eles Guarani ou não Guarani. Estas zonas distam até $50 \mathrm{~km}$ da área central do assentamento, contemplando desta forma o espaço físico-geográfico de um teko'á (cf. Noelli 1993). No caso do teko'á do Arroio Pelotas, a única zona de influência direta, relativa a fontes de matéria-prima seria a Área 3 (Escudo Sul-rio-grandense), em que ocorrem rochas graníticas e quartzosas, distando, por 


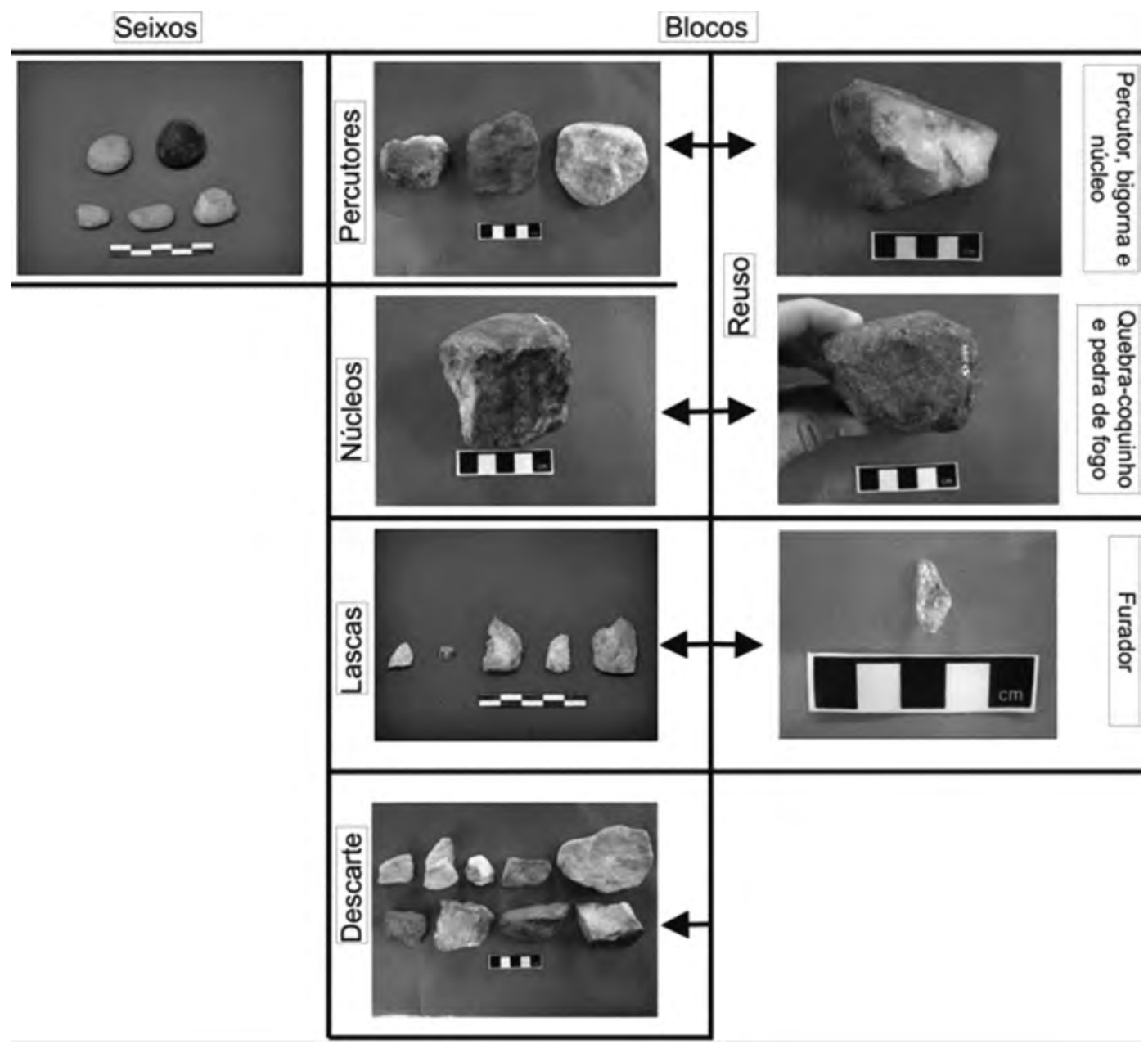

Fig. 18. Caracterização com fotos da cadeia operatória de uso do quartzo.

sua vez, $30 \mathrm{~km}$ aproximadamente. É interessante ressaltar também, que esta área de captação de recursos líticos é a matriz de implantação dos grupos Guarani na Serra do Sudeste, sendo, portanto, um território de relativa facilidade de acesso.

b) As Zonas de influência indireta, em contrapartida, são aquelas de exploração indireta e de menor intensidade, para as quais o deslocamento seria mais complicado na medida em que aumentam as distâncias. Neste caso, sugere-se que, do ponto de vista estratégico, as relações sociais de troca seriam mais usuais, o que permite obter, não somente os recursos desejados, mas também o fortalecimento das relações de parentesco, amizade, prestígio e alianças políticas.
Em outras palavras, as grandes distâncias do assentamento com relação às fontes líticas requerem o estabelecimento de redes de trocas, que envolvem um sistema que ultrapassa os limites do teko'á, pois, estas zonas distam mais de $50 \mathrm{~km}$ da área central do assentamento, o que atinge a esfera territorial do guará. No caso da área em estudo, observamos quatro zonas de influência indireta (Áreas 1 a 4), onde é possível captar o restante dos tipos de rochas encontradas nos sítios arqueológicos estudados no litoral da Laguna dos Patos.

As grandes distâncias entre a área central do assentamento e as áreas de captação de recursos líticos ainda traz outro ponto a discutir, que diz respeito ao grau de utilização de cada rocha, 
como suporte para fabrico de instrumentos líticos. Se considerarmos que a acessibilidade a cada zona de influência demanda um distinto e gradativo esforço para obter os recursos líticos, então, podemos imaginar que os padrões de uso e descarte dos artefatos deveriam variar também. Ou seja, devemos imaginar que a distância e a dificuldade em obter determinado tipo de matéria-prima faz com que a mesma, quando disponível, seja explorada até seu esgotamento visando diminuir desperdício.

Este mesmo raciocínio já foi realizado por Binford (1979). Procurando entender padrões de assentamento e variabilidade dos conjuntos artefatuais, o autor propôs através de analogia etnográfica direta com os grupos Nunamiut e estudos de tecno-tipologia lítica, que a funcionalidade do sítio pode ser inferida a partir dos aspectos de distância, manufatura e manuseio dos artefatos, o que gera padrões de descarte específicos. Desta forma, Binford desenvolve a teoria das tecnologias de curadoria, que são aquelas em que existe um investimento de manufatura, uso e reavivamento maior até seu descarte, se comparado às tecnologias expedientes, em que este investimento é menor.

Noelli (1993), também comenta este tipo de abordagem, em que pesa de um lado a distância das fontes de matéria-prima e a manutenção e conservação dos instrumentos:

"Esta ausência de matérias-primas nas proximidades obrigava a que fossem percorridas distâncias de até $60 \mathrm{~km}$ para encontrar rochas para funções específicas, adequadas à confecção de seus instrumentos. Devido às distâncias, a tecnologia deveria ser voltada para a manutenção e conservação dos equipamentos líticos, o que Binford denominou curated technologies (Binford 1979). Ao mesmo tempo em que os modelos teóricos sobre obtenção de recursos materiais estão direcionadas a uma tentativa de conservação mais acentuada, existem muitas informações históricas sobre os amplos deslocamentos para guerrear ou buscar matérias-primas. As pesquisas etnobiológicas sobre caçadas de populações tropicais também demonstram que várias atividades concomitantes eram desenvolvidas durante as saídas da aldeia, entre as quais a procura e localização de matéria-prima" (Noelli 1993: 122).
Levando esta diferenciação de tipos tecnológicos em consideração, podemos associar a questão das distâncias das fontes de matéria-prima ao padrão de manufatura, uso e descarte de determinados tipos de materiais líticos dos sítios do litoral, inferindo, desta forma, sobre as diferenças de investimento no tratamento de determinados tipos de materiais, o que nos permite constituir o seguinte quadro:

a) Indústria expediente: por um lado, temos os materiais obtidos na zona de influência direta (Escudo Sul-Riograndense), onde são obtidas rochas de quartzo e granito, as quais aparecem nos sítios do litoral, em sua maioria, como blocos e algumas poucas lascas. $\mathrm{Na}$ análise destes materiais notamos que os blocos raramente apresentam marcas de uso ou marcas de queima, demonstrando tratar-se de sobras de matéria-prima obtida e não utilizada. As lascas, por sua vez, são fabricadas e utilizadas sem haver a preocupação de reavivar o gume através de retoque. Neste sentido, a análise tecno-tipológica indica que o quartzo é utilizado pelos Guaranis do litoral sem haver a preocupação em esgotar a matéria-prima até o limite de sua capacidade, o que é corroborado pela análise dos poucos núcleos identificados nos sítios-acampamento, apresentando apenas duas ou três retiradas corticais. Isso indica também uma exploração pouco planejada e acentuada dos mesmos.

Considerando a facilidade de obtenção de blocos de quartzo, a baixa exploração e o alto índice de descarte deste tipo de matéria-prima nos sítios do litoral, sugerimos a ocorrência aqui de um exemplo de indústria expediente.

b) Indústria de curadoria: se de um lado, o quartzo e o granito sugerem um uso expediente, por outro lado, o restante das matérias-primas (calcedônia, basalto, arenito friável e arenito silicificado) indica que tenha havido um investimento de obtenção e uso mais acentuado, caracterizando um caso de indústria de curadoria.

No que se refere à obtenção de matéria-prima é de se notar que distâncias que variam de $65 \mathrm{~km}$ até $200 \mathrm{~km}$ requerem um investimento em estratégia, que ultrapassa a esfera do teko'á, adentrando os limites do guará, exigindo, portanto, a valorização destas matérias quando obtidas. 
A caracterização das cadeias operatórias do material lítico dos sítios do litoral, sobretudo do sítio PS-03-Totó, confirmou a hipótese de valorização da calcedônia e do arenito friável. Notamos um processo de manufatura, uso, reciclagem e descarte da calcedônia que visou a uma operacionalização cautelosa da matéria-prima, através de lascamento bipolar para aquisição de lâminas e lamelas e demais lascas finas como furadores, instrumentos cortantes (facas) e raspadores. Em segundo lugar, chamamos atenção para os afiadores em canaleta confeccionados em arenito friável, que demonstraram estarem altamente explorados, pois a maioria das peças apresenta sulcos em ambas as faces e, por vezes, também nas laterais das placas. Os alisadores em arenito também demonstraram bastante exploração, inclusive com a presença de peças que foram usadas para as duas funções. Esta exploração acentuada das peças deveria ocorrer, em nosso ponto de vista, devido à dificuldade em obtenção do arenito, sendo necessário, portanto, utilizar os suportes disponíveis.

No que se refere à função dos sítios arqueológicos e aos aspectos espaciais referentes a áreas de atividade intrassítio, a caracterização das indústrias líticas proposta corrobora a existência de dois tipos de sítios:

a) a aldeia do Totó, com uma quantidade de material lítico bem superior em relação aos outros sítios do litoral. A variabilidade de tipos tecnológicos e matérias-primas líticas também é um fator importante, em que notamos a presença de materiais manufaturados em diferentes tipos de rochas, lascados e polidos para a confecção de variados instrumentos indicando um planejamento e valorização dos suportes em vias de aperfeiçoar a exploração destes. Identificamos práticas de reciclagem das lascas e exploração acentuada dos núcleos, havendo o descarte de materiais na lixeira apenas quando já não evidenciassem mais potencial de uso. $\mathrm{O}$ material lítico analisado demonstrou bastante uso, sobretudo naqueles artefatos coletados na estrutura de terra preta. As lascas de calcedônia são bastante delgadas e há um grande percentual de fragmentos de lascas. Além disso, os afiadores em canaleta parecem ter sido explorados até a exaustão, visto que têm diversos sulcos, em geral, em todas as suas faces ativas.

O alto grau de exploração das peças e a sua grande quantidade de materiais presente na estrutura de terra preta, em contraposição aos materiais presentes na trincheira são dados importantes para pensarmos a função das áreas de atividade. A área de trincheira, com uma densidade menor de materiais arqueológicos foi interpretada como um piso de habitação, cuja limpeza através do ato de varrer incorreu no transporte de dejetos orgânicos e inorgânicos para a lixeira a três metros ao lado, à beira do arroio Totó. ${ }^{?}$

b) Os sítio-acampamento, com uma quantidade de material lítico inferior em termos de quantidade e variabilidade tecnológica, uma cadeia operatória caracterizada pela indústria de quartzo, que como vimos, demonstrou ser um tipo de material de relativo fácil acesso, de estilo menos sofisticado e mais frequentemente descartado sem sinais de utilização. Os sítios-acampamento são interpretados como áreas de atividades específicas, provavelmente para caça e/ou coleta de recursos lacustres (peixes, camarão, siri, etc.). As atividades realizadas nestes sítios geraram um padrão de uso dos materiais líticos aparentemente sem preocupação em explorar de forma acentuada a matéria-prima, bem como um descarte de materiais que não gera estruturas arqueológicas bem marcadas no registro, fator este recorrente em todos os sítios-acampamento.

\section{Conclusões}

Neste trabalho buscamos apresentar uma descrição detalhada da cadeia operatória dos três tipos de matéria-prima mais frequentes nos sítios litorâneos da margem sudoeste da Laguna dos Patos - RS. Esta descrição atende à necessidade de um olhar diferenciado para o material lítico dos sítios arqueológicos Guarani, cujas

(7) Ver esta discussão espacial articulando os outros tipos de vestígios em Milheira 2008a, Milheira 2008b, Milheira \& Alves 2009 e Milheira \& Ulguim 2009. 
peças são raramente descritas nas publicações e, quando o são, geralmente ficam relegadas a uma apresentação tecno-tipológica complementar ao que já foi dito sobre a cerâmica.

Na medida em que as "pedras" compõem o inventário dos sítios Guarani, é importante decodificar nelas elementos da cultura que as cunhou e que testemunham: tecnologia, comportamento cultural nas suas relações sociais, redes de comércio e territorialidade. Em outras palavras, procuramos demonstrar como o material lítico pode ser pensado como vetor indicativo de um processo cultural que envolve atividades planejadas, desde a obtenção de matérias-primas até o descarte final, ou seja, um ciclo de vida dos objetos que nos permite apreender questões tecnológicas específicas da cultura Guarani.

Tentamos também entender a cadeia operatória de um ponto de vista comparativo, pensando a relação entre as diferentes matérias-primas, as técnicas empregadas e os padrões de uso e descarte dos materiais em cada sítio. Logo, procuramos refletir sobre a função dos sítios arqueológicos, suas áreas de atividade e sua participação no sistema regional de assentamento. Esta comparação, integrando outros sítios arqueológicos, não somente do litoral, mas de outras regiões deve ser pesquisada a fim de ca- racterizarmos as diferentes formas de tratamento das rochas pelos grupos Guarani e entendermos o significado da variabilidade artefatual.

Se a cerâmica vem servindo como suporte para pensar aspectos da manutenção da estrutura histórica de longa duração, refletida pela continuidade dos padrões estilísticos e tecnológicos, nas suas mais variadas escalas territoriais, por que as rochas não seriam significativas sobre estes aspectos? Por que não considerar que os grupos Guarani também refletiriam seu modo de ser (ñande rekó) no estilo como manipulavam as rochas? Quais as relações funcionais entre as rochas e as vasilhas cerâmicas e o que isso representa em termos sistêmicos para a cultura Guarani? Enfim, são apenas questões amplas, que esperamos, sirvam como pontos de reflexão.

\section{Agradecimentos}

Agradeço aos colegas Anderson Marques Garcia e Aluisio Alves pela leitura e discussão sobre as cadeias operatórias dos materiais líticos, assim como pelas discussões geradas nas atividades de experimentação. Aos colegas Paulo DeBlasis e Adriana Schmidt Dias também agradeço pela leitura e encorajamento na publicação deste texto.

MILHEIRA, R.G. The Guarani and their lithic artifacts. A technological study in the south of Brazil. R. Museu Arq. Etn., São Paulo, n. 21, p. 129-152, 2011.

\begin{abstract}
In this work we present a technological analyses to characterize a lithic artifacts operatorie's chain from archaeological sites of Guarani culture, located on southwest border of Laguna dos Patos and Serra do Sudeste - Rio Grande do Sul. Looking at variation on strategies for obtaining, manufacturing, using and discarding of raw materials as chalcedony, sandstone and quartz, we propose a discussion about the dimension of the Guarani dominion territory, curated and situational technologies, artifacts function and discard pattern.
\end{abstract}

Keywords: Guarani Archaeology - Lithic technology - Strategies for obtaining resources - Dominion Territory - Use and discard of materials. 


\section{Referências bibliográficas}

ASSIS, V.S.

1996 Da Espacialidade Tupinambá. Dissertação de Mestrado, Porto Alegre: PUCRS.

BINFORD, L.R.

1979 Organization and formation process: looking at curated technologies. Journal of Anthropological Research, 35 (3): 269-286.

BROCHADO, J.P.

1984 An Ecological Model of the Spread of Pottery and Agriculture Into Eastern South America. Tese de Doutorado. Carbondale: University of Illinois at Urbana-Champaign.

DIAS, A.S.

2003 Sistemas de Assentamento e Estilo Tecnológico: Uma Proposta Interpretativa para a Ocupação Pré-Colonial do Alto Vale do Rio dos Sinos, Rio Grande do Sul. Tese de Doutorado, São Paulo: USP.

DIAS, A.S.; HOELTZ, S.E.

1997 Proposta Metodológica para o estudo das indústrias líticas do sul do Brasil. Revista do CEPA, 21 (25). Santa Cruz do Sul, UNISC: 21-62.

2002 Havia uma pedra no meio do caminho: indústrias líticas das tradições Taquara e Guarani na região do Alto Rio dos Sinos. Revista do CEPA, 26 (35/36). Santa Cruz do Sul, UNISC: 181-214.

FAUSTO, C.

2001 Inimigos Fiéis. História Guerra e Xamanismo na Amazônia. São Paulo: EDUSP.

FOGAÇA, E.

2006 Um objeto lítico. Além da forma, a estrutura. Revista Canindé, 7: 11-36.

GARLET, I.J.

1997 Mobilidade Mbyá: História e Significação. Dissertação de Mestrado, Porto Alegre: PUC-RS.

LA SALVIA, F.; BROCHADO, J.P.

1989 Cerâmica Guarani. Porto Alegre: Posenato $\&$ Cultura.

LUZ, J.A.R; FACCIO, N.B.

2006 A pedra lascada dos índios Guarani, pré-históricos, a partir de uma análise tecnológica. Anais do V Encontro da SAB-sul. Rio Grande: FURG.

MARTH, J.D.; KOESTER, E.; ARNDT, A.L.

2008 Mapa geológico-geomorfológico do município de Pelotas, RS. Anais do XVII Congresso de Iniciação Científica da UFPEL.
MELLO, P.J.C.; VIANA, S.A.

2001 Possibilidade de interpretação da cadeia operatória de produção de instrumentos líticos - Sítio Pedreira (MT). Revista do Museu de Arqueologia e Etnologia, 11, São Paulo: 109-124.

MILHEIRA, R.G.

2008a Território e Estratégia de Assentamento Guarani na Planície Sudoeste da Laguna dos Patos e Serra do Sudeste - RS. Dissertação de Mestrado, São Paulo: MAE-USP.

2008b Um modelo de ocupação regional Guarani no sul do Brasil. Revista do Museu de Arqueologia e Etnologia, 18, São Paulo: 19-46.

MILHEIRA, R.G.; ALVES, A.G.

2009 O sítio Guarani PS-03-Totó. Uma abordagem cultural e sistêmica. Revista da Sociedade de Arqueologia Brasileira, 1: 15-42.

MILHEIRA, R.G.; ULGUIM, P.F.

2009 Uma contribuição para a Zooarqueologia em sítios Guarani do litoral sul do Brasil, Laguna dos Patos, Pelotas-RS: estratégias de assentamento, aspectos alimentares e função de sítio. Revista CLIO, Série Arqueológica (UFPE), 1: 84-107.

MORAIS, J.L.

2007 Tecnotipologia Lítica. Erechim: Habilis.

NOELLI, F.S.

1993 Sem Tekohá não há Tekó (em busca de um modelo etnoarqueológico da subsistência e da aldeia Guarani aplicada a uma área de domínio no delta do Jacuí-RS). Dissertação de Mestrado, Porto Alegre: PUC-RS.

1997 Distâncias entre as áreas de captação de recursos líticos e o sítio arqueológico do arroio do Conde, Rio Grande do Sul. Revista do CEPA, 21 (26). Santa Cruz do Sul, UNISC: 113-131.

NOELLI, F.S.; DIAS, A.S.

1995 Complementos históricos ao estudo funcional da indústria lítica Guarani. Revista do CEPA, 19 (22). Santa Cruz do Sul, UNISC: $7-24$.

NOVAES, S. C.

1983 Habitações Indígenas. São Paulo: EDUSP. PLOG, S.

1976 Relative efficiencies of sampling techniques for archaeological surveys. In: Flannery, K. (Ed.) The Early Mesoamerican Village. Londres, Academic Press: 136-158. 
PROUS, A.

1986/ Os artefatos líticos. Elementos descritivos

1990 classificatórios. Arquivos do Museu Histórico e Natural da UFMG. Belo Horizonte, 11: 1-88.

RADAMBRASIL

1986 Levantamento de Recursos Naturais da secretaria do Planejamento da Presidência da República. IBGE, v. 33.

REDMAN, C.

1973 Multistage fieldwork and analytical techniques. American Antiquity, 38 (1): 61-79.

ROGGE, J.H.

2004 Fenômenos de Fronteira: Um Estudo das Situações de Contato entre Portadores das Tradições Cerâmicas Pré-históricas no Rio Grande do Sul. Tese de Doutorado, São Leopoldo: UNISINOS.

SCHIFFER, M.B.

1972 Archaeological Context and Systemic Context. American Antiquity, 37 (2): 156 165.

SCHMITZ, P.I.

1976 Sítios de pesca lacustre em Rio Grande, RS, Brasil. Tese de Livre Docência, São Leopoldo: Instituto Anchietano de Pesquisas.
1987 Formation Processes of the Archaeological Record. Albuquerque: University of New Mexico Press.

SHEPARD, A.O.

1985 Ceramics for the Archaeologist. Washington D.C.: Carnegie Institution of Washington [1956].

SOARES, A.L.R.

1997 Guarani. Organização Social e Arqueologia. Porto Alegre: EDIPUCRS.

2005 Contribuição para a Arqueologia Guarani. Tese de Doutorado, São Paulo: USP.

TOMAZELLI, L.J.; VILLWOCK, J.A.

2000 O Cenozóico no Rio Grande do Sul: Geologia da Planície Costeira. In: Holz, M.; De Ros, L.F. (Eds.) Geologia do Rio Grande do Sul. Porto Alegre: CIGO/UFRGS.

ZEDEÑO, M.N.

1997 Landscapes, land use, and the history of territory formation: an example from puebloan southwest. Journal of Archaeological Method and Theory, 4 (1): 63-103.

2000 What People Make of Places. A Behavioral Cartography. In: Schiffer, M.B. (Ed.) Social Theory in Archaeology. Utah, University of Utah Press: 97-111. 